James Madison University

JMU Scholarly Commons

Libraries

Libraries

$9-9-2020$

\title{
Faculty Perceptions of Academic Librarians: Experts, Connectors, and Resource Stewards
}

Jody Fagan

James Madison University, faganjc@jmu.edu

Elizabeth Price

James Madison University, price2el@jmu.edu

Hillary Ostermiller

Columbia College Chicago, hostermiller@colum.edu

Lara Sapp

James Madison University, sapple@jmu.edu

Follow this and additional works at: https://commons.lib.jmu.edu/letfspubs

Part of the Library and Information Science Commons

\section{Recommended Citation}

Jody Condit Fagan, Hillary Ostermiller, Elizabeth Price \& Lara Sapp (2020) Faculty Perceptions of Academic Librarians: Experts, Connectors, and Resource Stewards, DOI: 10.1080/

13614533.2020.1819354

This Article is brought to you for free and open access by the Libraries at JMU Scholarly Commons. It has been accepted for inclusion in Libraries by an authorized administrator of JMU Scholarly Commons. For more information, please contact dc_admin@jmu.edu. 


\title{
Faculty Perceptions of Academic Librarians: Experts, Connectors, and Resource Stewards
}

\author{
Jody Condit Fagan, Hillary Ostermiller, Elizabeth Price \& Lara Sapp \\ James Madison University \\ Author Note \\ JMU Libraries, James Madison University, Harrisonburg, VA \\ 22807 \\ faganjc@jmu.edu; hostermiller@colum.edu; price2el@jmu.edu; \\ sapple@jmu.edu
}

This is an Accepted Manuscript of an article published by Taylor \& Francis in the journal

New Review of Academic Librarianship on September 9, 2020, available online:

https://www.tandfonline.com/doi/full/10.1080/13614533.2020.1819354 
A survey concerning perceptions of academic librarians was conducted at a large, 4-year university with three populations: librarians, faculty, and undergraduate students. This paper presents results from the faculty population, with comparison to the librarian sample. The major research questions address perceptions about what librarians know (expertise and skills), what librarians do (role and duties), and what librarians are like (motivations and affective characteristics). Results showed faculty perceptions to be more in-line overall with librarians' perceptions of themselves than the literature might otherwise indicate, at least in domains where the faculty are actively engaged. Faculty also identified a role not explicitly mentioned on the survey: that of librarians as conduits between students and faculty. Gaps between librarian and faculty perceptions still exist relating to the extraordinary extent and diversity of librarian knowledge, skills, duties, and capacities, and with respect to the extent of librarians teaching. The study points to an ongoing need for marketing of library services and continued demonstration of library value.

Keywords: academic librarians, perceptions, stereotypes, faculty, higher education 


\section{Introduction}

This is the third article in a series about the perceptions of academic librarians held by librarians, non-librarian faculty (hereafter “faculty”), and students at one institution. The first article presented a literature review and study introduction (Fagan, Ostermiller, Price, \& Sapp, 2020a), the second presented results from the librarian sample (Fagan, Ostermiller, Price, \& Sapp, 2020b), and this article presents results from the faculty sample. A publication concerning student perceptions is planned to follow. For the purposes of this paper, "librarians” will be used to mean "academic librarians” since they were the subject of this survey.

\section{Methodology}

This study used an online survey to collect data from non-librarian faculty at James Madison University (JMU). The IRB-approved instrument was adapted from earlier surveys by Pastine and Hernon (1977) and Fagan (2003) to collect both quantitative and qualitative data through a mix of closed and open-ended questions. The authors adapted the survey questions slightly to compare responses across three populations: librarians, undergraduate students, and non-librarian faculty (survey instrument can be found in Appendix.) Information for a question about librarian salaries was based on the 2016 Library Journal placement and salary survey (Allard, 2017).

The survey for this study was created using Qualtrics survey software and remained open for four weeks in fall 2018. This survey was open to all full-time instructional faculty teaching at JMU in fall $2018(n=1,061)$. It was distributed first via the internal faculty listserv. The authors then sent direct emails to approximately 50 faculty who taught classes that were targeted in a similar student perceptions survey during the previous academic year. A total of 176 faculty responded, of which 126 responses were considered valid in terms of completeness, for a response rate of $11.9 \%$. Quantitative data from the survey were analysed 
using SPSS version 23. Qualitative data from the survey were coded using NVivo software version 12 and sorted into categories by themes according to the question. Two authors independently coded all responses, with occasional discussion about adding new categories based on the data, and reconciliation of the boundaries of certain categories. After this initial review, the two authors agreed on at least $90 \%$ of the coded references according to NVivo's coding comparison. References the software flagged as divergent coding were reviewed together and discussed until consensus was reached, or, the item was moved into a Not Coded Elsewhere (NCE) category. Ultimately, the authors agreed on greater than $96 \%$ of the coded references.

\section{Limitations}

This is a case study comparing findings across populations at one institution, and therefore the findings cannot be generalised to other institutions. The authors hope this methodology can serve as a protocol for other institutions to replicate, although we recognize some limitations here; and we offer additional suggestions for improving the survey instrument in the Methodological Improvements section.

This survey was adapted from the one created for JMU's student population, which also formed the basis for the survey used for the librarian population. This means some dimensions of librarian work that might concern librarians and faculty exclusively could be underrepresented. For example, the instrument did not offer an explicit opportunity for faculty to talk about the diversity of communications between librarians and faculty. Searching for Communication as a concept across all qualitative comments yielded only 8 mentions. In contrast, this study’s literature review (Fagan, Ostermiller, Price, \& Sapp, 2020a, p. 18) had identified that faculty placed high importance on librarians updating faculty on library services, consulting with faculty to support instructional needs, and conveying faculty opinions to the library administration (Ochola \& Jones, 2001; Schulte \& Sherwill- 
Navarro, 2009; Yang, 2000). The fact that communication did not emerge more strongly in this survey seems likely related to the instrument’s design.

From the student survey, some questions were kept the same, some were adjusted for the non-librarian faculty population, some were added, and some were omitted. A few of the adaptations for the different populations changed the meaning of the question. For example, the question "What skills do you think librarians have that are valuable to you?” (Q11) prompts faculty to think about their own experiences, while the same question for both the librarian and student populations relates to the student experience. These nuances have required the researchers to be careful and rigorous in how different sets of data are compared.

Using similar questions for different populations changed how the questions were perceived. As the questions were originally written for students, a few faculty respondents objected to the tone of some items in the survey. When prompted for any additional comments (Q18), one respondent noted that "Elements of this survey were very condescending.” It is possible that the tone of certain questions might have influenced how the faculty responded.

\section{Results}

\section{Demographics}

Out of 1,061 faculty employed at JMU (Office of Institutional Research, 2019), we received 126 valid responses, for a response rate of $11.9 \%$. Chi-square goodness of fit tests found the distribution of males and females ${ }^{1}$ in the sample to be significantly different from the JMU population $\left(x^{2}(1)=7.13, p=0.007\right)$ and the distribution of full- and part-time faculty ${ }^{2}$

\footnotetext{
${ }^{1}$ Four faculty preferred not to say, and one responded "Other" with no text response. These 5 were not included in the chi-square test.

${ }^{2}$ Ten faculty said they had multiple roles, and 1 faculty responded "Other"; there was no opportunity for text response. These 11 were not included in the chi-square test.
} 
was significantly different than the population $\left(x^{2}(1)=10.45, p=0.001\right)$. While JMU's faculty population is reported as $49 \%$ female and 51\% male, our sample identified as 59\% female, 37\% male, $1 \%$ other, and 4\% preferred not to say (JMU OIR, 2018, Table 4-2). The proportion of JMU full-time faculty is reported as $76 \%$ versus $24 \%$ part-time faculty, and our sample identified as $89 \%$ full-time and 11\% part-time (JMU OIR, 2018, Table 4-7). The distribution of faculty by college in our sample was not significantly different from the distribution in the JMU population $\left(\mathrm{x}^{2}(7)=13.43, p=0.06\right)$, meaning our sample generally represents the proportions by college in the JMU population.

\section{What Librarians Know: Librarian expertise and skills / Value for librarians' skills}

Most faculty were aware that the master's degree is the minimum level of educational qualification for an entry-level librarian at JMU (79\%), with 8.9\% responding only a bachelor's degree is necessary, $6.5 \%$ responding that more than one master's degree is necessary, and $4.8 \%$ responding that a doctoral degree is necessary (Q15). In response to the question, "How much do you think an entry-level JMU librarian makes per year?” (Q10), most respondents thought librarians made $\$ 40,000-\$ 49,999$ per year, followed by $\$ 50,000$ 59,999 per year. This is quite different from librarians’ actual entry-level salaries at JMU. The most recent five hires fell into either $\$ 50,000-59,000$ per year or $\$ 60,000-69,000$ per year (See Figure 1). 
Figure 1. Faculty perceptions of entry-level librarian salaries and actual entrylevel librarian salaries (Q10).

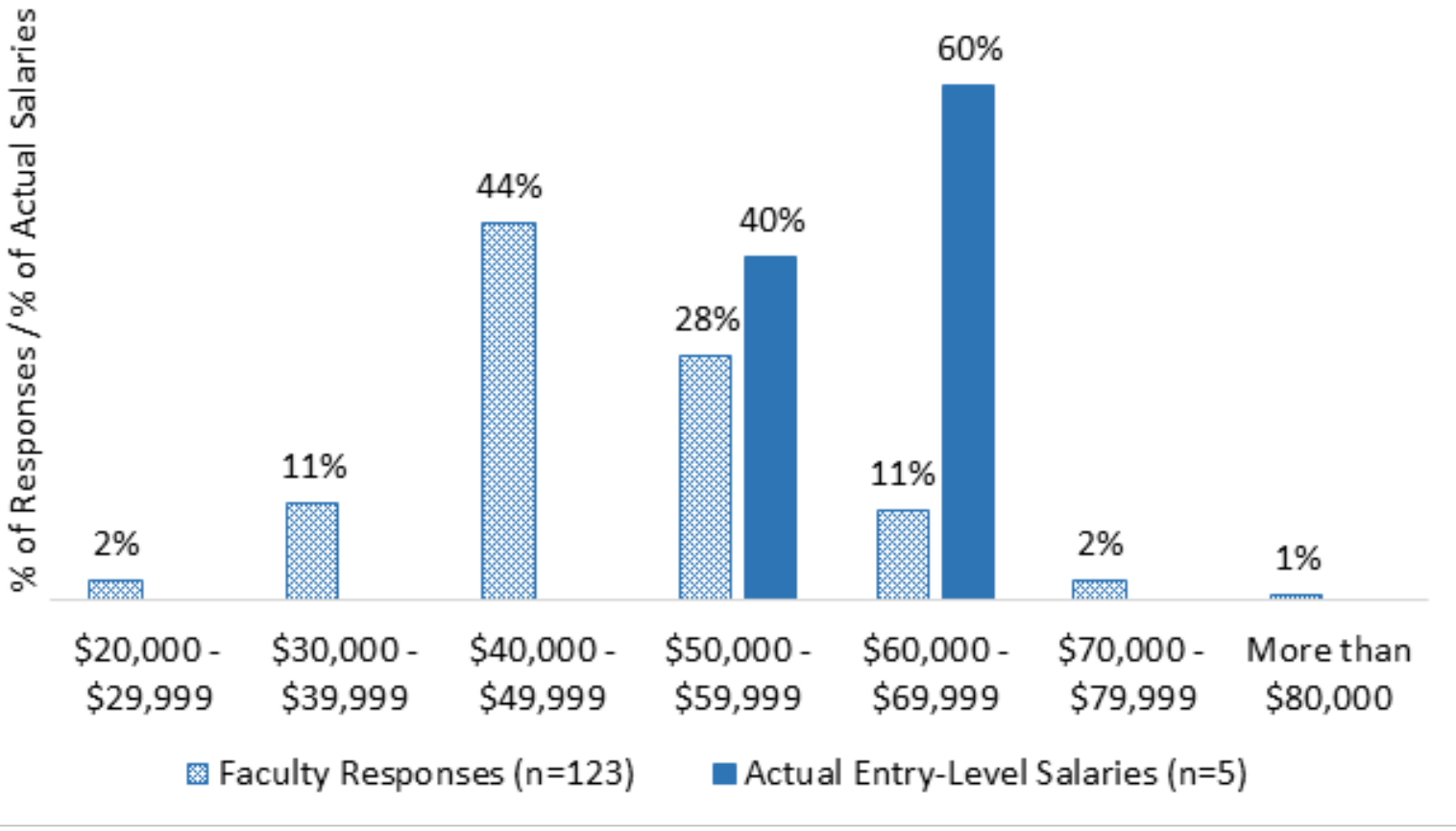

Eighty-nine (71\%) faculty responded to the question "What do you think academic librarians learn in their library classes? Please write at least three topics you think are covered in library school classes” (Q16). Topics given across responses were coded into several broad categories as defined in Table 1.

Table 1. Definitions for coding "What skills do you think librarians have..." and "What do you think academic librarians learn in their library classes?” (Q11, Q12, Q16).

\begin{tabular}{|c|c|c|c|}
\hline $\begin{array}{l}\text { Category / } \\
\text { Subcategory }\end{array}$ & Description & $\begin{array}{l}\text { Example responses } \\
\text { in } \\
\text { Librarian survey } \\
\text { (Q5, Q6 \& Q9) }\end{array}$ & $\begin{array}{l}\text { Example responses in } \\
\text { Faculty Survey } \\
\text { (Q11, Q12 \& Q16) }\end{array}$ \\
\hline $\begin{array}{l}\text { Data \& Information } \\
\text { Management }\end{array}$ & $\begin{array}{l}\text { Specific mentions of } \\
\text { managing data and/or } \\
\text { information. }\end{array}$ & N/A & $\begin{array}{l}\text { “Data management skills" } \\
\text { "Structures of information } \\
\text { organization and management” }\end{array}$ \\
\hline \begin{tabular}{|l|} 
Expertise / \\
Evaluating \\
Information
\end{tabular} & $\begin{array}{l}\text { An ability to determine } \\
\text { the quality of information } \\
\text { or sources. }\end{array}$ & $\begin{array}{l}\text { "Discerning quality } \\
\text { information.” }\end{array}$ & $\begin{array}{l}\text { "How to instruct faculty and students } \\
\text { on strategies for resource } \\
\text { identification" } \\
\text { "They help provide and evaluate } \\
\text { access of all variety of information" }\end{array}$ \\
\hline $\begin{array}{l}\text { Expertise / General } \\
\text { Library-Related } \\
\text { Knowledge }\end{array}$ & $\begin{array}{l}\text { Librarians "knowing } \\
\text { stuff.” }\end{array}$ & $\begin{array}{l}\text { "An understanding of } \\
\text { how information flows } \\
\text { through society." }\end{array}$ & $\begin{array}{l}\text { "A broad general knowledge of } \\
\text { current resources, literature, and trends } \\
\text { in all fields" } \\
\text { "Professional knowledge" }\end{array}$ \\
\hline $\begin{array}{l}\text { Expertise / } \\
\text { Generating } \\
\text { Knowledge }\end{array}$ & & N/A & $\begin{array}{l}\text { "Conducting their own research" } \\
\text { "Produce scholarship related to } \\
\text { information literacies" }\end{array}$ \\
\hline
\end{tabular}




\begin{tabular}{|c|c|c|c|}
\hline \begin{tabular}{|l|} 
Expertise / \\
Information ethics
\end{tabular} & $\begin{array}{l}\text { Ethical use of information, } \\
\text { including } \\
\text { copyright, author's rights, } \\
\text { citation, and plagiarism. }\end{array}$ & $\mathrm{N} / \mathrm{A}$ & $\begin{array}{l}\text { "Legal and ethical } \\
\text { issues e.g. intellectual property” } \\
\text { "Citing of research used” }\end{array}$ \\
\hline $\begin{array}{l}\text { Expertise / } \\
\text { Information Literacy }\end{array}$ & $\begin{array}{l}\text { Specific mentions of } \\
\text { "information literacy." }\end{array}$ & $\mathrm{N} / \mathrm{A}$ & $\begin{array}{l}\text { "Information literacy skills” } \\
\text { “Assisting university/faculty with } \\
\text { research, writing, and/or information } \\
\text { literacy” }\end{array}$ \\
\hline $\begin{array}{l}\text { Expertise / Library \& } \\
\text { Information Science }\end{array}$ & $\begin{array}{l}\text { Library or Information } \\
\text { Science as academic } \\
\text { disciplines. }\end{array}$ & N/A & $\begin{array}{l}\text { “Library information history” } \\
\text { "Basic library science” }\end{array}$ \\
\hline $\begin{array}{l}\text { Expertise / Locating } \\
\text { \& Accessing } \\
\text { Information }\end{array}$ & $\begin{array}{l}\text { Furnishing or finding } \\
\text { needed information. } \\
\text { Usually also coded with a } \\
\text { particular type of resource } \\
\text { (databases, books, articles, } \\
\text { data, etc.). }\end{array}$ & $\begin{array}{l}\text { "Deciphering where to } \\
\text { find information" } \\
\text { "Knowledge about how } \\
\text { to navigate an } \\
\text { overwhelming ocean of } \\
\text { information" }\end{array}$ & $\begin{array}{l}\text { "Using and making available } \\
\text { electronic tools (databases etc.)" } \\
\text { "How to manipulate a word search" }\end{array}$ \\
\hline $\begin{array}{l}\text { Expertise / } \\
\text { Preservation \& } \\
\text { Archives }\end{array}$ & $\begin{array}{l}\text { Preservation of } \\
\text { information and materials, } \\
\text { including archival } \\
\text { practices. }\end{array}$ & $\mathrm{N} / \mathrm{A}$ & $\begin{array}{l}\text { "Archive strategies and techniques" } \\
\text { "Methods of preserving information" }\end{array}$ \\
\hline Expertise / Research & $\begin{array}{l}\text { Research as either a noun, } \\
\text { adjective or a verb. } \\
\text { Usually focused on } \\
\text { processes. }\end{array}$ & $\begin{array}{l}\text { “Ability to help } \\
\text { students see research as } \\
\text { a process” } \\
\text { "Thinking about } \\
\text { different ways to } \\
\text { approach a research } \\
\text { problem” }\end{array}$ & $\begin{array}{l}\text { "Research design and how to support } \\
\text { research" } \\
\text { "How to select and evaluate research } \\
\text { resources (journals, etc.)” }\end{array}$ \\
\hline $\begin{array}{l}\text { Expertise / Subject } \\
\text { Areas }\end{array}$ & $\begin{array}{l}\text { References either } \\
\text { knowledge across many } \\
\text { topics (General Education } \\
\text { expertise) or subject } \\
\text { specialties depending on } \\
\text { position. }\end{array}$ & $\begin{array}{l}\text { "Subject expertise" } \\
\text { "Awareness of } \\
\text { curriculum and subject } \\
\text { area" }\end{array}$ & $\begin{array}{l}\text { “Accessing subject-specific research } \\
\text { and putting it in a space where people } \\
\text { from that area can then use it” } \\
\text { "Knowledge of academic discipline } \\
\text { (2nd MA)” }\end{array}$ \\
\hline \begin{tabular}{|l} 
Expertise / \\
Technology
\end{tabular} & $\begin{array}{l}\text { Computers, software, or } \\
\text { technology management } \\
\text { skills. }\end{array}$ & $\begin{array}{l}\text { “Creating accessible } \\
\text { documents, } \\
\text { spreadsheets, and web } \\
\text { materials” } \\
\text { “Human-computer } \\
\text { interaction” }\end{array}$ & $\begin{array}{l}\text { “Library-related technology” } \\
\text { “Instructional technology” }\end{array}$ \\
\hline $\begin{array}{l}\text { Expertise / Writing \& } \\
\text { Papers }\end{array}$ & $\begin{array}{l}\text { Writing, formatting } \\
\text { research papers. }\end{array}$ & N/A & $\begin{array}{l}\text { “Helping students to do proper } \\
\text { research and write proper research” } \\
\text { "How to write and cite research } \\
\text { papers” }\end{array}$ \\
\hline $\begin{array}{l}\text { Higher-Order } \\
\text { Thinking } \\
\end{array}$ & $\begin{array}{l}\text { Analytical or problem- } \\
\text { solving skills. }\end{array}$ & $\begin{array}{l}\text { "Critical thinking" } \\
\text { "abstract thinking" }\end{array}$ & $\begin{array}{l}\text { "Ability to synthesize information” } \\
\text { "Creative problem solving” }\end{array}$ \\
\hline Interpersonal Skills & $\begin{array}{l}\text { Communication skills, } \\
\text { customer service skills, } \\
\text { social skills, or personal } \\
\text { qualities such as “patient” } \\
\text { or "intelligent.” }\end{array}$ & $\begin{array}{l}\text { "Empathy" } \\
\text { "Curiosity" }\end{array}$ & $\begin{array}{l}\text { "Effective communication skills" } \\
\text { "Customer service type stuff” }\end{array}$ \\
\hline Library Facilities & $\begin{array}{l}\text { About the library as a } \\
\text { building, as a place. }\end{array}$ & N/A & $\begin{array}{l}\text { "Maintaining the library" } \\
\text { "How to manage facilities" }\end{array}$ \\
\hline Organization & $\begin{array}{l}\text { Arranging items logically } \\
\text { (e.g., classification } \\
\text { systems) or the skills and } \\
\text { knowledge required to } \\
\text { carry out these tasks. }\end{array}$ & "organizational skills" & $\begin{array}{l}\text { “Classifying } \\
\text { and cataloging information” } \\
\text { “Structures of information } \\
\text { organization and management” }\end{array}$ \\
\hline
\end{tabular}




\begin{tabular}{|c|c|c|c|}
\hline $\begin{array}{l}\text { Reference } \\
\text { Skills \& Reference } \\
\text { Interview }\end{array}$ & $\begin{array}{l}\text { Specific mentions of } \\
\text { "reference” in the context } \\
\text { of helping users identify } \\
\text { what they need. }\end{array}$ & $\begin{array}{l}\text { “The 'reference } \\
\text { interview' and how } \\
\text { people don't always } \\
\text { know how to ask for } \\
\text { what they need.” } \\
\text { "'Reference skills" }\end{array}$ & $\begin{array}{l}\text { "Reference" } \\
\text { "Information trends (how people } \\
\text { access information and what } \\
\text { information they want)" }\end{array}$ \\
\hline Resources & $\begin{array}{l}\text { Materials generically } \\
\text { (holdings, resources, stuff, } \\
\text { etc.) or specifically (data, } \\
\text { articles, books, films, } \\
\text { etc.); collection } \\
\text { management. Often also } \\
\text { coded as expertise in } \\
\text { locating/accessing } \\
\text { information. }\end{array}$ & $\begin{array}{l}\text { "Collection } \\
\text { management skills" } \\
\text { "Ability to effectively } \\
\text { search databases and } \\
\text { utilize database } \\
\text { features to locate } \\
\text { relevant results" }\end{array}$ & $\begin{array}{l}\text { "Research tools and resources" } \\
\text { "Acquiring and managing } \\
\text { collections” }\end{array}$ \\
\hline $\begin{array}{l}\text { Teaching } \\
\text { \& Pedagogy }\end{array}$ & $\begin{array}{l}\text { Teaching and instruction } \\
\text { for individuals and } \\
\text { groups, as well as } \\
\text { mentions of student } \\
\text { learning or pedagogical } \\
\text { practices. Also includes } \\
\text { assistance provided to } \\
\text { improve others' teaching. }\end{array}$ & $\begin{array}{l}\text { "Ability to teach } \\
\text { students about } \\
\text { searching for and } \\
\text { evaluating information } \\
\text { critically" } \\
\text { "Instruction" }\end{array}$ & $\begin{array}{l}\text { "Supporting learning and use of } \\
\text { research skills, information synthesis, } \\
\text { evaluating sources, and all } \\
\text { around library/research literacy." } \\
\text { "Teach students how to do research" }\end{array}$ \\
\hline
\end{tabular}

Categories that accounted for at least $3 \%$ of the total coded references $(n=344)$ are

highlighted in Figure 2. Expertise was the largest category with $48 \%$ of all coded references.

It was sub-coded to capture various aspects of librarian work $(n=168)$. The largest sub-

category was Research (51), followed by Technology (31), Locating \& Accessing

Information (19), and Information Ethics (15). Other types of expertise that were

acknowledged by respondents but failed to meet the 3\% threshold included the categories

Evaluating Information, General Library-Related Knowledge, Information Literacy, Library

\& Information Science, and Writing \& Papers. 
Figure 2. What do you think academic librarians learn in their library classes? (Q16); Total Respondents=89; Total coded references $=344$.

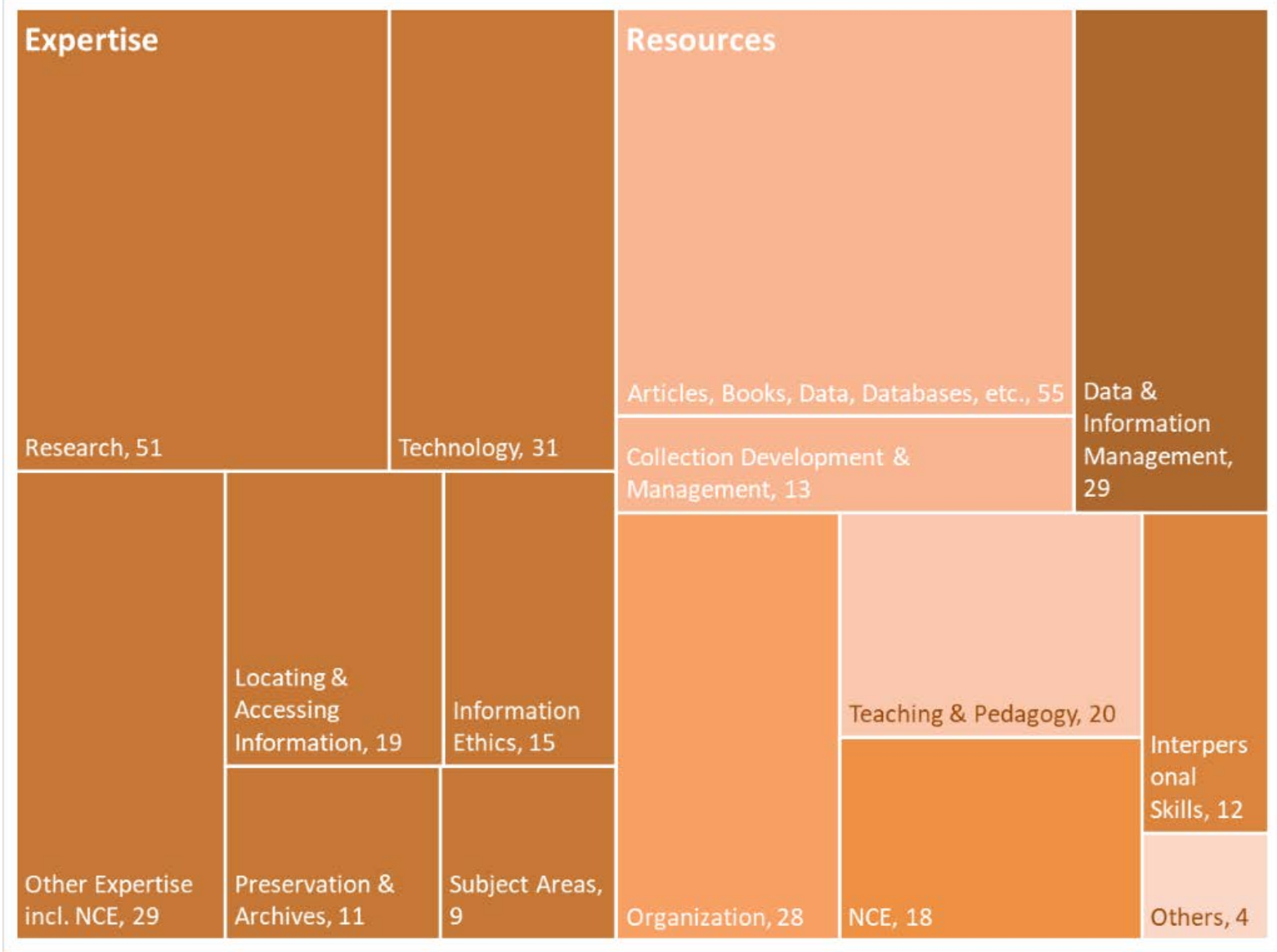

The next largest category was Resources (68 mentions; 20\% of all coded references),

which sometimes specified types such as databases, books, articles, data, etc., but most often was used generically to describe library "stuff.” Thirteen references coded in this category encompassed the concept of librarians learning to select or curate university holdings, described as Collection Development \& Management. Other significant categories included Organization (28 mentions), which encompassed variations on the phrases classifying and cataloging and the specific systems used to organize books (the Dewey Decimal System was mentioned 4 times, while Library of Congress Classification System was mentioned once); Data \& Information Management (29 mentions); Teaching \& Pedagogy (20 mentions); and Interpersonal Skills (12 mentions). About $5 \%$ of responses $(n=18)$ did not fit in defined categories and were grouped in a Not Coded Elsewhere node. 
Ninety-four (75\%) faculty responded to the question "What skills do you think librarians have that are valuable to you?” (Q11) for a total of 286 coded references.

Individuals' responses contained multiple reasons, and as before, only categories included in at least 3\% of the total coded references are highlighted in Figure 3.

Figure 3. What skills do you think librarians have that are valuable to you? (Q11); Total Respondents=94; Total coded references $=286$.

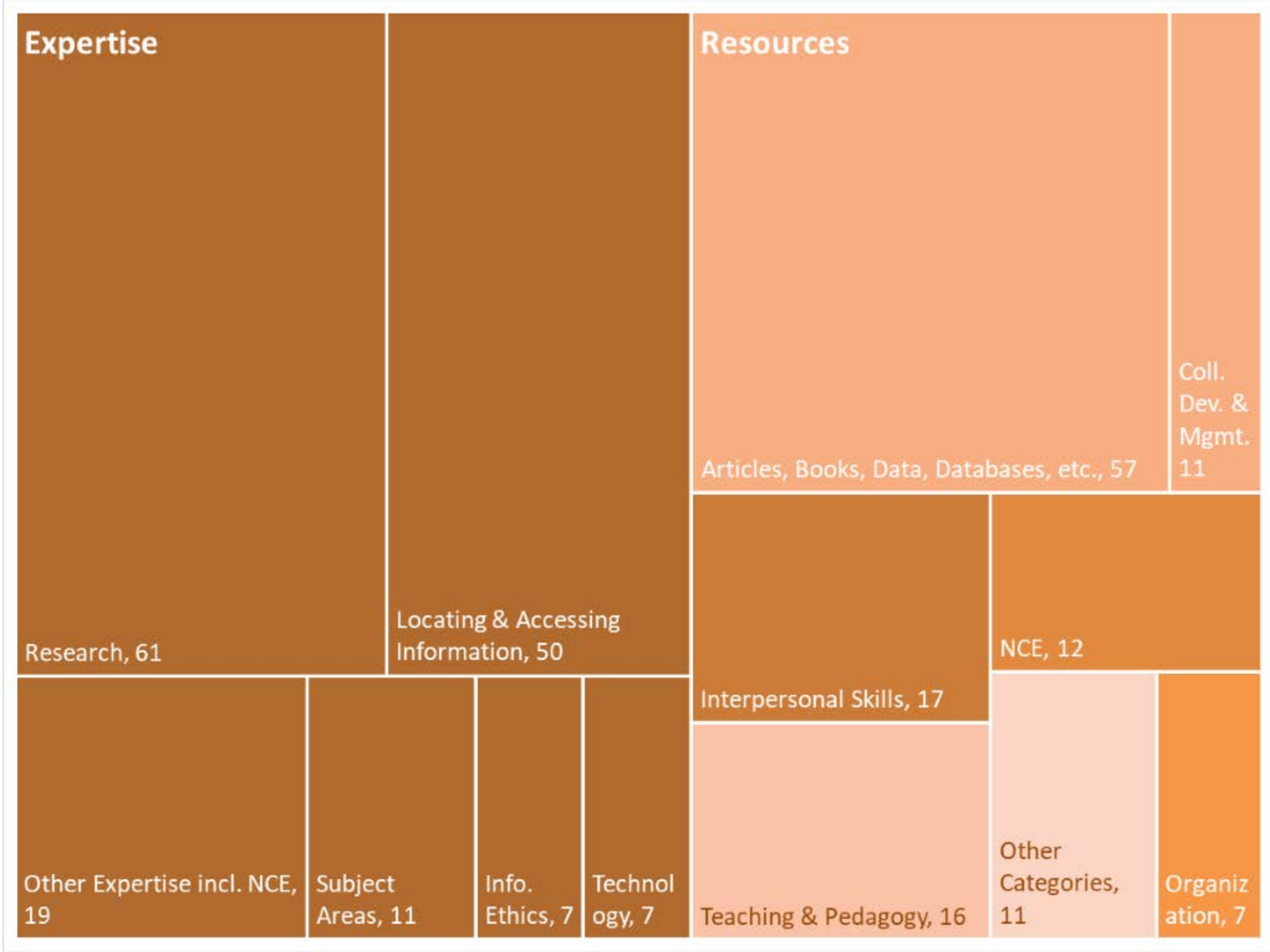

Faculty most frequently mentioned librarians’ Expertise as the skill most valuable to them, accounting for $55 \%$ of all coded references $(n=147)$. The abilities to conduct and support Research (61 mentions) and skills in Locating \& Accessing Information (50) were the top two sub-categories. Some faculty particularly highlighted librarians' knowledge of their Subject Areas (11 mentions). Others mentioned Technology (7) or concepts like Information Ethics (7).

Developing or maintaining the Resource collections that support faculty research was the next most frequently mentioned skill (68 combined mentions, or $24 \%$ of all coded 
references). Interpersonal Skills (17 mentions, 6\%), Teaching \& Pedagogy (16 mentions, 6\%) and Organization (7 mentions, 3\%) completed the list. Categories that failed to meet the 3\% threshold included Higher-Order Thinking (7), Data \& Information Management (3), and Library Facilities (1). About $4 \%$ of responses $(n=12)$ did not fit in defined categories and were grouped in a Not Coded Elsewhere node. A few of these responses directly mentioned the connection that librarians have to students ("working with students," “student support”). For example, one respondent commented specifically that librarians’ "awareness of student culture" is valuable to them, indicating that librarians can be viewed as a conduit between students and faculty.

Eighty-seven (69\%) faculty responded to the question "What skills do you think librarians have that are valuable to the university?” (Q12). Individuals' responses contained multiple reasons, and only categories included in at least 3\% of the total coded references ( $n=283)$ are highlighted in Figure 4. 
Figure 4. What skills do you think librarians have that are valuable to the university? (Q12); Total Respondents=87; Total coded references=283.

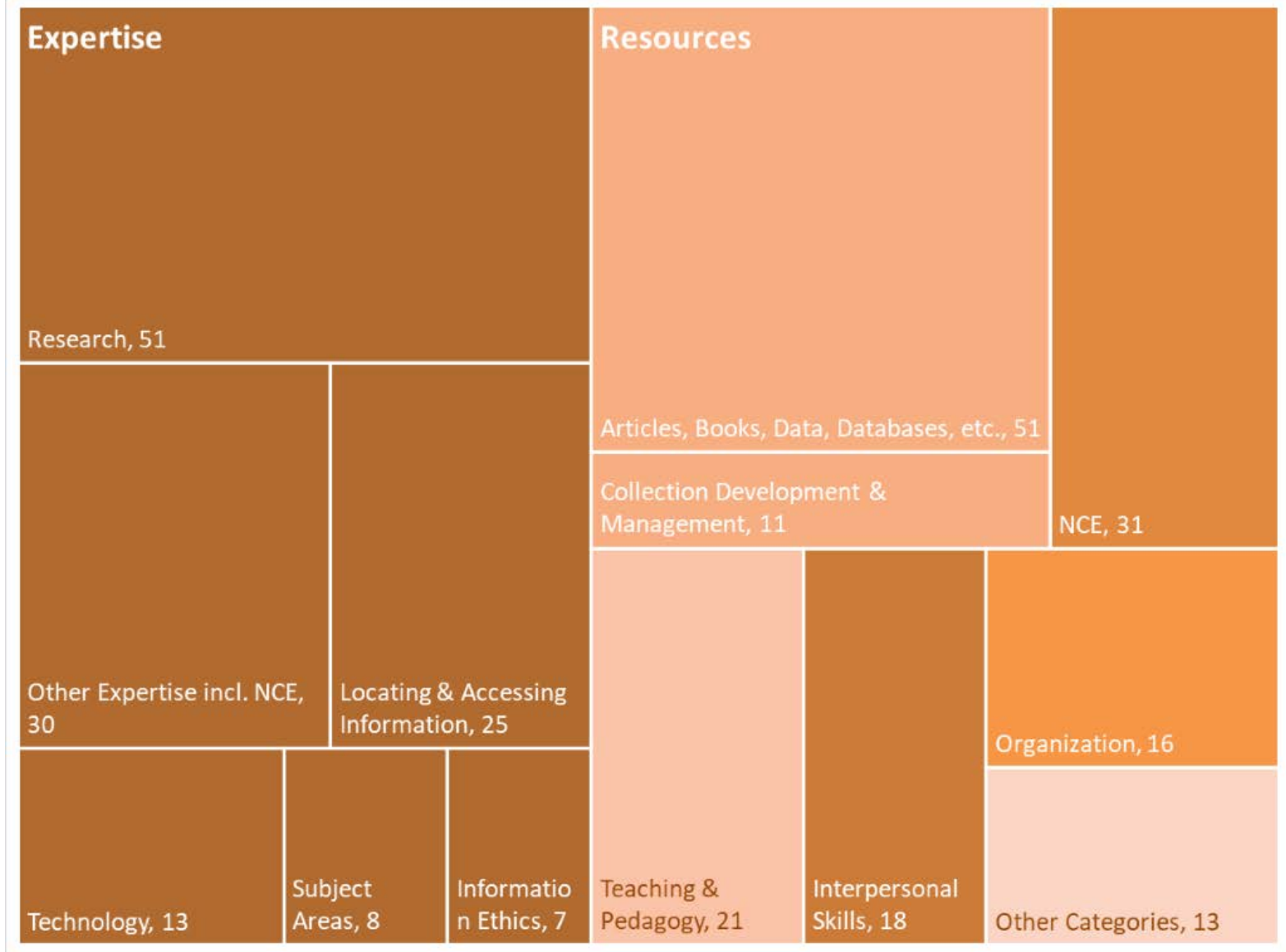

Similarly, to Q11, faculty focused on librarians’ Expertise with Research (51 mentions) and Locating \& Accessing Information (25); this category accounted for $46 \%$ of coded references ( $n=131)$. Resources were mentioned next (62 mentions, 22\% of coded references). Organization (16, 6\%), Teaching \& Pedagogy (21 mentions, 7\%) and Interpersonal Skills $(18,7 \%)$ rounded out the list. Categories that failed to meet the 3\% threshold included Higher-Order Thinking (7 mentions), Data \& Information Management (3) and Library Facilities (1). About $11 \%$ of responses $(n=31)$ did not fit in defined categories and were grouped in a Not Coded Elsewhere node. 


\section{What Librarians Do: Duties and role of librarians}

A large majority of respondents (78\%) knew librarians are faculty at JMU, although 7\% thought they were not faculty (Table 2, Q8). Respondents were not sure whether librarians were faculty at every university (Q9), but some of these responses might be due to the lack of an "only at some universities” option. Sixty-three percent of faculty said they asked to speak to a librarian (Q7). However, only 41\% said they could tell which workers are librarians, 25\% were sure they could not tell, and 31\% were not sure (Q6), perhaps because they can only tell whether some workers are librarians.

Table 2. Faculty perceptions of librarian characteristics (Q7, Q8, Q9, Q10).

In JMU Libraries, can you tell which workers are librarians?

\begin{tabular}{|c|c|c|c|}
\hline Yes & No & Not sure & Missing \\
\hline $41 \%$ & $25 \%$ & $31 \%$ & $2 \%$ \\
\hline $63 \%$ & $34 \%$ & $2 \%$ & $2 \%$ \\
\hline $78 \%$ & $7 \%$ & $13 \%$ & $2 \%$ \\
\hline $22 \%$ & $30 \%$ & $46 \%$ & $2 \%$ \\
\hline
\end{tabular}

On the set of questions asking, "How often do you think academic librarians perform the following duties?” (Q5), there was one missing response for 9 items and two missing responses for 3 items; the other items had no missing data. There were three items with more than 6 Not Sure Responses: Repairing Damaged Materials (12), Issuing Library Cards (8), Processing Fines (7), and Planning Special Events (6). Subsequently, Not Sure was treated as missing data.

A majority of respondents indicated that librarians Frequently engaged in seven of the 26 listed duties (Giving Subject-Specific Help to Students for Research; Giving General Help to Students for Research; Buying Books, Journals and Electronic Material; Giving General Help to Faculty for Research; Teaching Research Skills; Creating Subject Guides; and Analysing the Effectiveness of Library Services and Programs). Respondents said that 
librarians never engaged in four of the 26 listed duties (Working in Starbucks; Issuing

Library Cards; Picking Up Trash/Cleaning the Library; and Providing IT Support for Campus

Wi-Fi) (see Figure 5).

Figure 5. How often do you think academic librarians perform the following duties? (Q5).

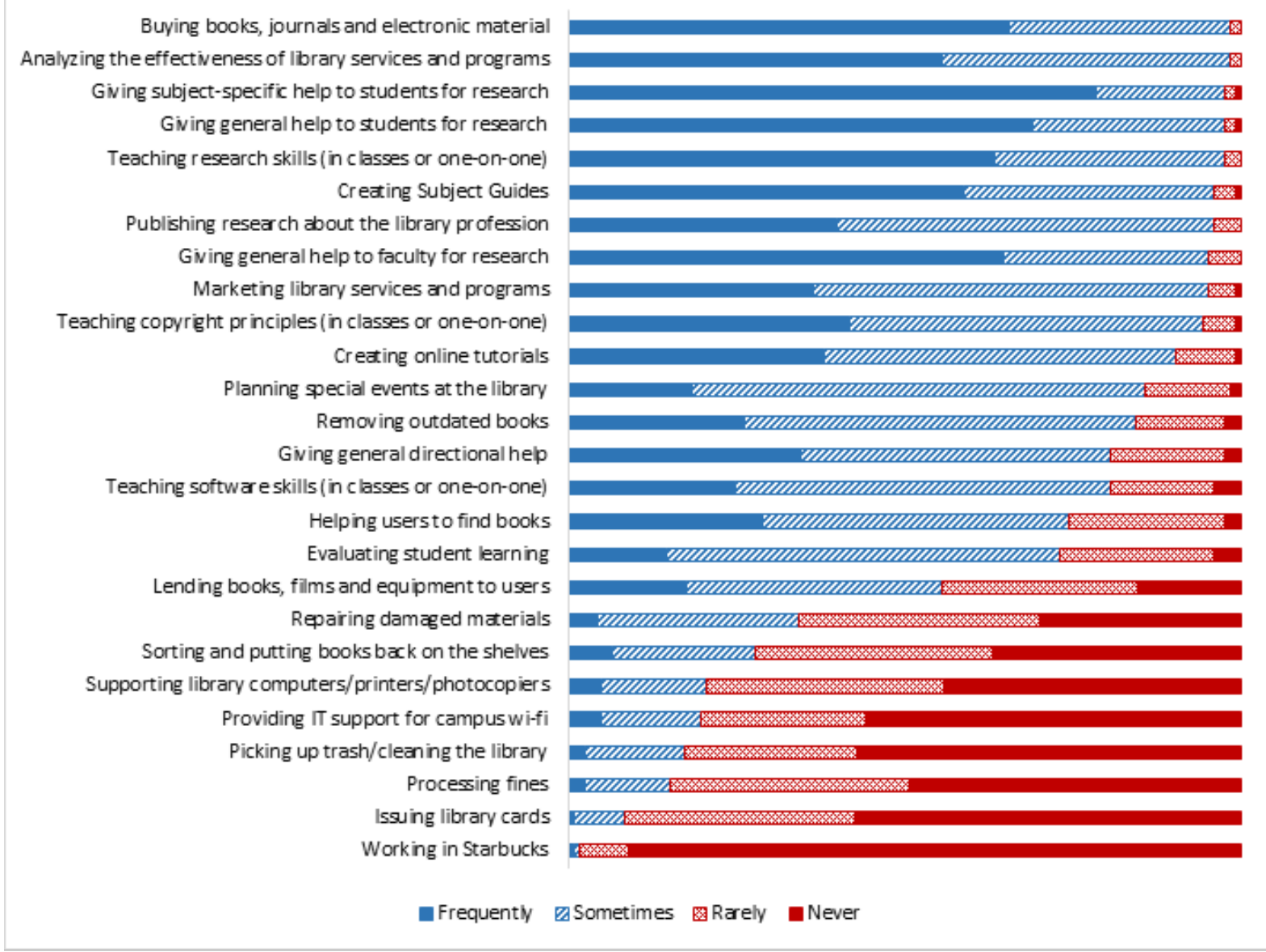

Relationships among the items comprising Q5, "How often do you think academic librarians perform the following duties?”, were explored using a simple correlation matrix of the items. ${ }^{3}$ We classified relationships as moderate if the correlation was greater than 0.3 , and high if greater than 0.6. We observed three clusters (see Figure 6).

${ }^{3}$ An exploratory factor analysis was attempted, but even after removing some of the items with low correlations with other items, the determinant of the correlation matrix was not sufficient to support the method. 
Figure 6. Clustered Faculty Perceptions of Librarian Duties.
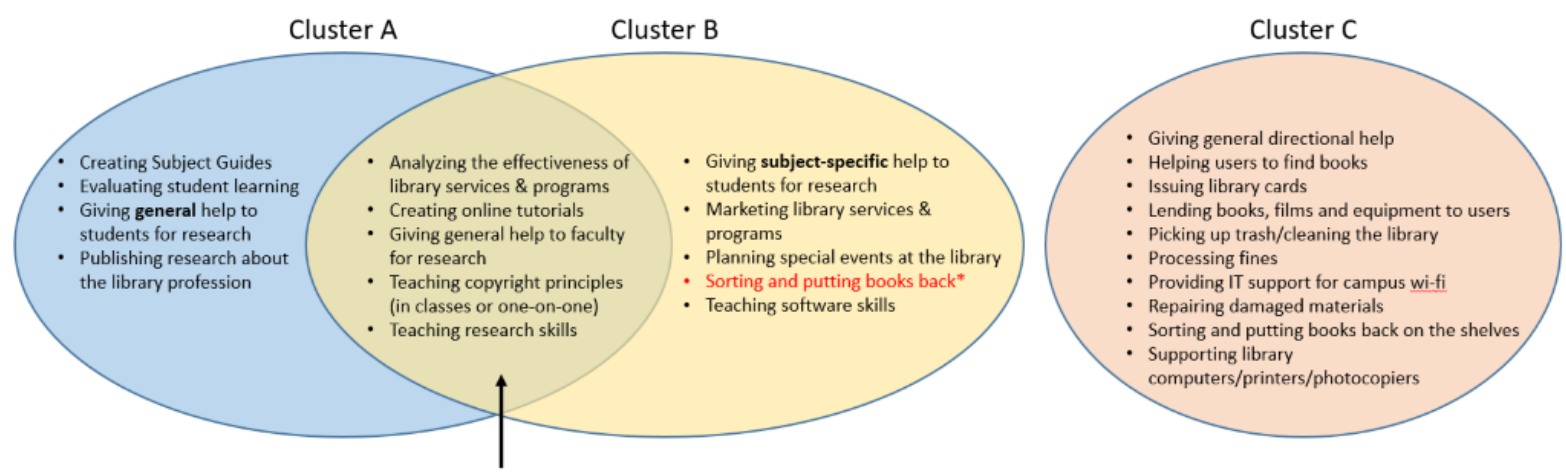

Responses equally correlated with Clusters A and B

*Indicates a negative correlation; four items were not placed in a group because they correlated with only one item.

Four items were not placed in a group because they correlated with only one other item in the set:

- Buying Books, Journals and Electronic Material

- Removing Outdated Books

- Working in Starbucks.

For example, Buying Books, Journals, and Electronic Material had a moderate correlation (.35) with Creating Subject Guides, but did not have notable correlations with the other items in Cluster A.

\section{What Librarians Are Like: Motivations and affective characteristics}

Respondents were asked to rank from 1 to 10 a list of reasons librarians chose to become librarians, where 1 was the top reason that librarians want to be librarians (Q4). (There were no missing responses to this item.) Figure 7 shows the aggregate responses sorted by mean, where 1 is the top reason. The standard deviations suggest some variability among respondents; 1.63 was the average $s d$, not including “other.” Eight respondents wrote in reasons for the response "Other": two declining to answer the question, and the other six 
saying: "they want to support college student learning and development," "they want to contribute to human knowledge,” "they love knowledge,” “They are intellectuals and want to be immersed in learning and discovering new things. (I sometimes wish my degree was in library science.),” “quest for knowledge,” and “They are awesome people.”

Figure 7. Faculty and librarian perceptions of reasons librarians became librarians (Q4) (Average Rank on a scale of 1-10, with Standard Deviation Error Bars).

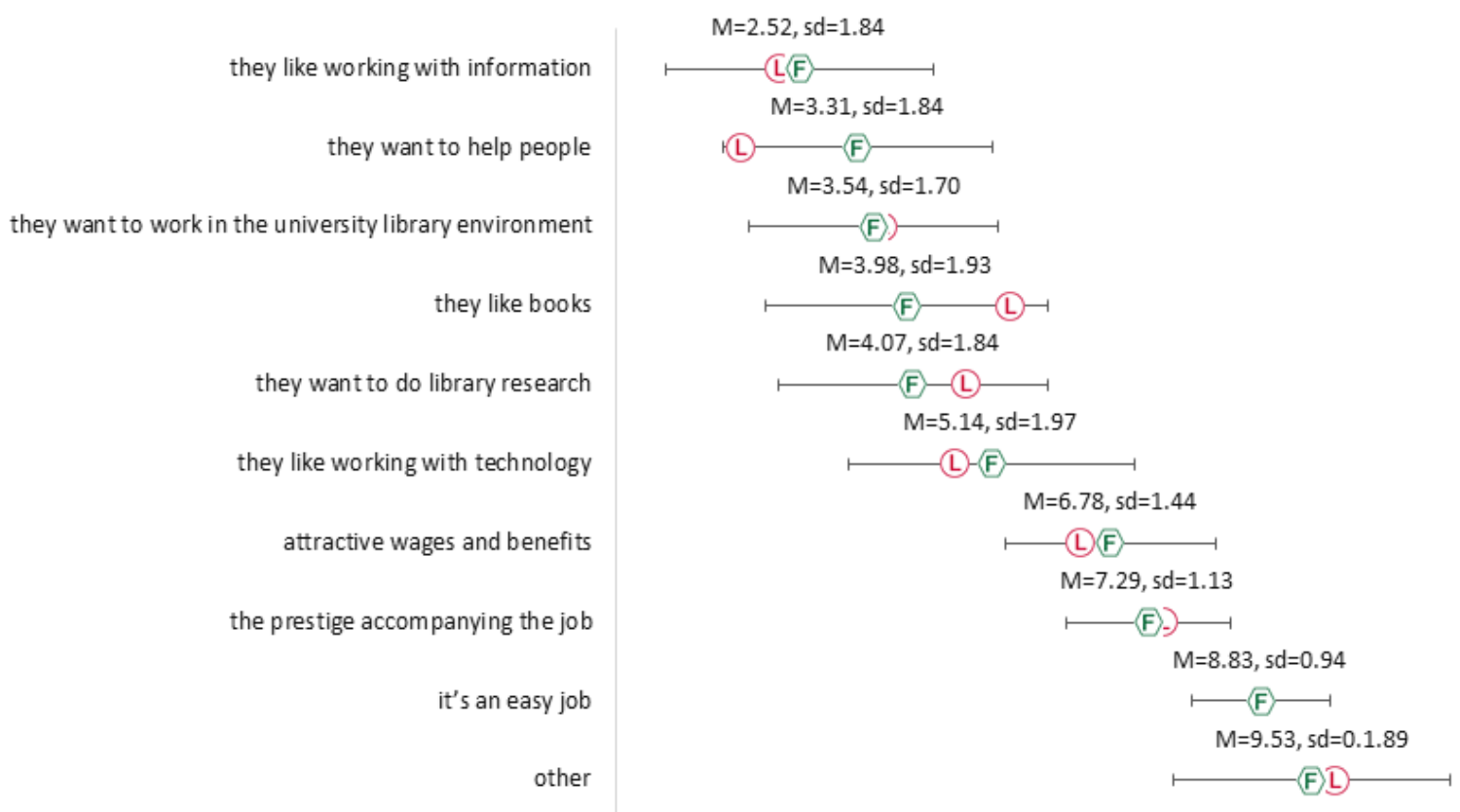

For the question set "Please read the following statements carefully and indicate your level of agreement” (Q17), if a respondent answered fewer than 10 of the 25 items, their response was excluded from analysis; thus, 9 responses were excluded (remaining sample size=117). After doing so, there were three items that had one missing response each. The item "There are more female librarians than male librarians" elicited 40 Not Sure responses (34\% of the sample), and the item "There is enough diversity (race, ethnicity, age, gender, etc.) among librarians” elicited 35 Not Sure responses (30\% of the sample). The other items had 7 or fewer Not Sure responses. Not Sure responses were changed to Missing for the remainder of analysis. 
Figure 8 shows faculty respondents' level of agreement with various motivational and affective statements about librarians. For eight items, a majority chose Strongly Agree:

- Librarians know what they're doing

- Librarians like helping students

- Librarians have knowledge that is practical to me

- Librarians help students learn to do things themselves

- Librarians are friendly and pleasant

- It is important to employ librarians of diverse ages, races, and gender

- Librarians are easy to talk to

- Librarians respect students’ intelligence. 
Figure 8. Faculty levels of agreement with motivational and affective statements (Q17). Note: See Appendix LPL-1 for full statements. Not Sure was a response option but was treated as missing data. Sorted by total positive responses descending, then total negative responses ascending.

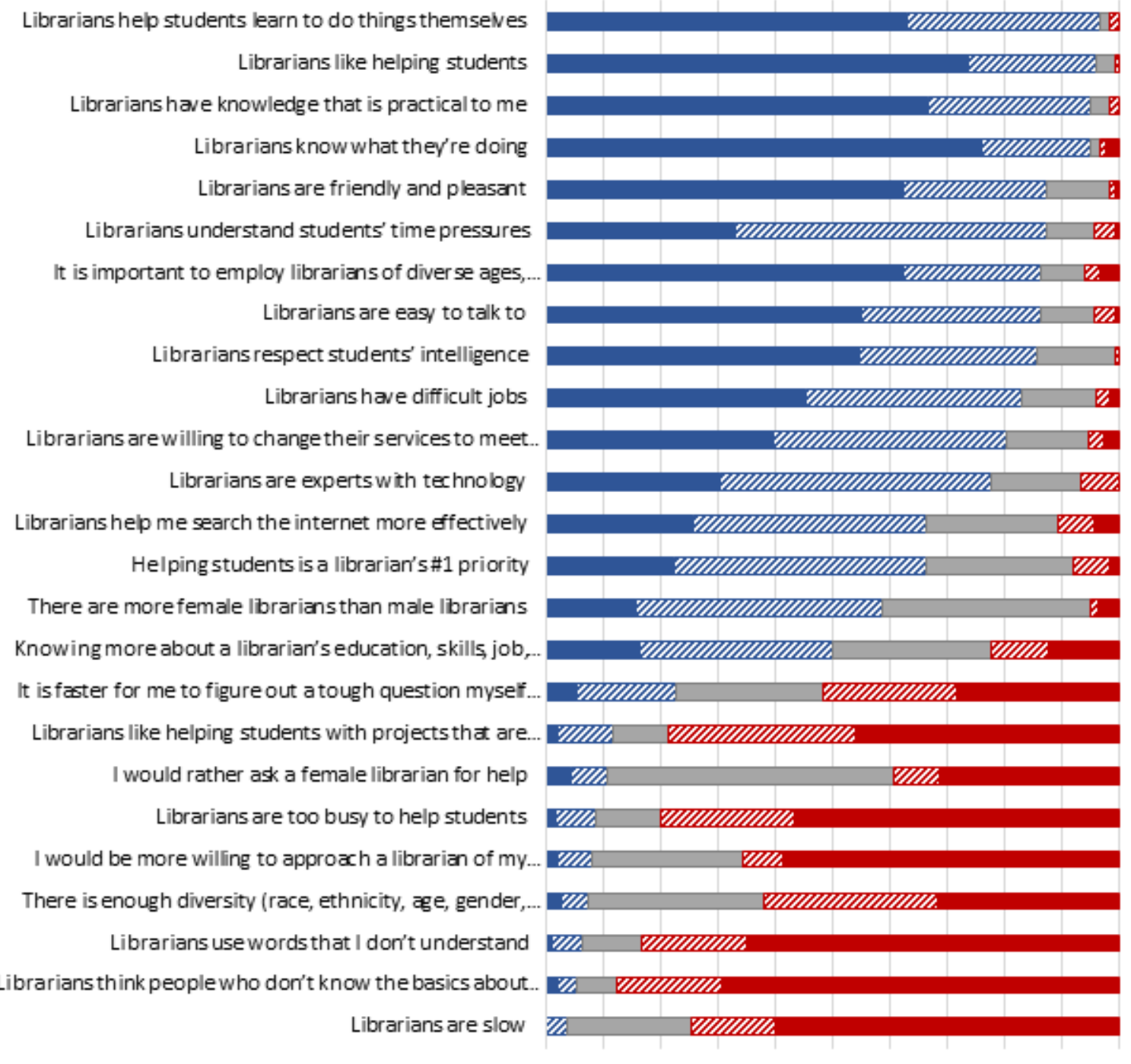

$\square$ Strongly Agree $\Downarrow$ Somewhat Agree $\square$ Nether Agree nor Disagree $\circlearrowright$ Somewhat Disagree $\square$ Strongly Disagree

For an additional seven items the majority chose either Strongly Agree or Somewhat Agree. Five items elicited Strongly Disagree responses from a majority of respondents:

- Librarians think people who don’t know the basics about the library are stupid

- Librarians use words that I don’t understand

- Librarians are slow

- I would be more willing to approach a librarian of my own race or ethnicity 
- Librarians are too busy to help students.

An additional three items elicited Strongly Disagree or Somewhat Disagree. The item with the highest proportion of Neither Agree nor Disagree responses was "I would rather ask a female librarian for help.”

Item correlations for Q17 were examined visually to explore possible relationships among the affective items. ${ }^{4}$ Correlations with an absolute value greater than 0.3 were deemed moderate; those greater than .6, high. We observed 3 clusters, with some items overlapping two clusters (see Figure 9).

Figure 9. Clustered faculty responses (Q18).
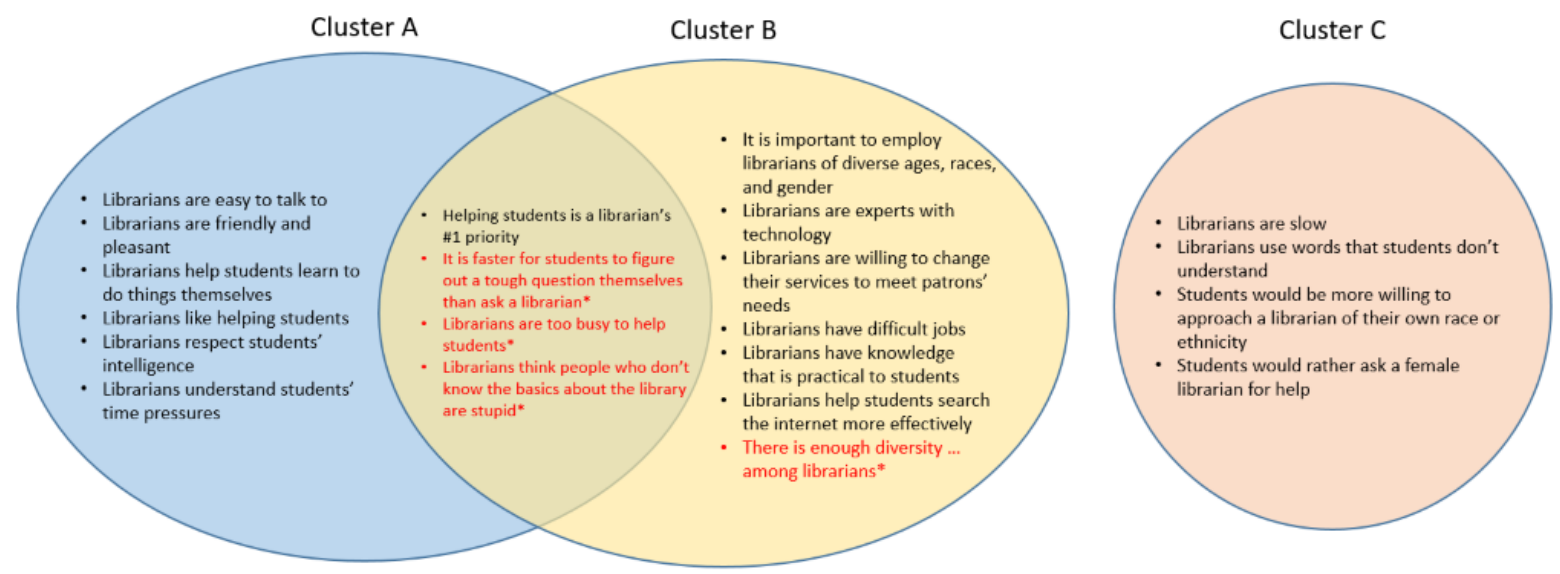

Note: *Indicates a negative correlation; four items were not placed in a group because they were correlated with three or fewer items.

Four items were not placed in a group because they were correlated with three or fewer items:

- Librarians like helping students with projects that are due tomorrow

- Librarians know what they're doing

\footnotetext{
${ }^{4}$ The determinant of the correlation matrix for Q27-28 was insufficient for an exploratory factor analysis, probably due to the large number of Not Sure items.
} 
- Knowing more about a librarian's education, skills, job, and personality help students decide whether or not to ask them for help

- There are more female librarians than male librarians.

“Students would rather ask a female librarian for help" also correlated with three or fewer items but was placed in Cluster $\mathrm{C}$ because it had moderate correlations with two items in that cluster.

Eighty-four (67\%) faculty responded to the question "Why do you like to ask librarians questions?” (Q13). Reasons given across responses were coded into several broad categories, as shown in Figure 10. Definitions for these categories are shown in Table 3. Some individuals' responses contained multiple reasons, and only categories included in at least $3 \%$ of the total coded references are highlighted in the figure $(n=178)$. 
Figure 10. Why faculty like to ask librarians questions (Q13); Total Respondents=84; Total coded references $=178$.

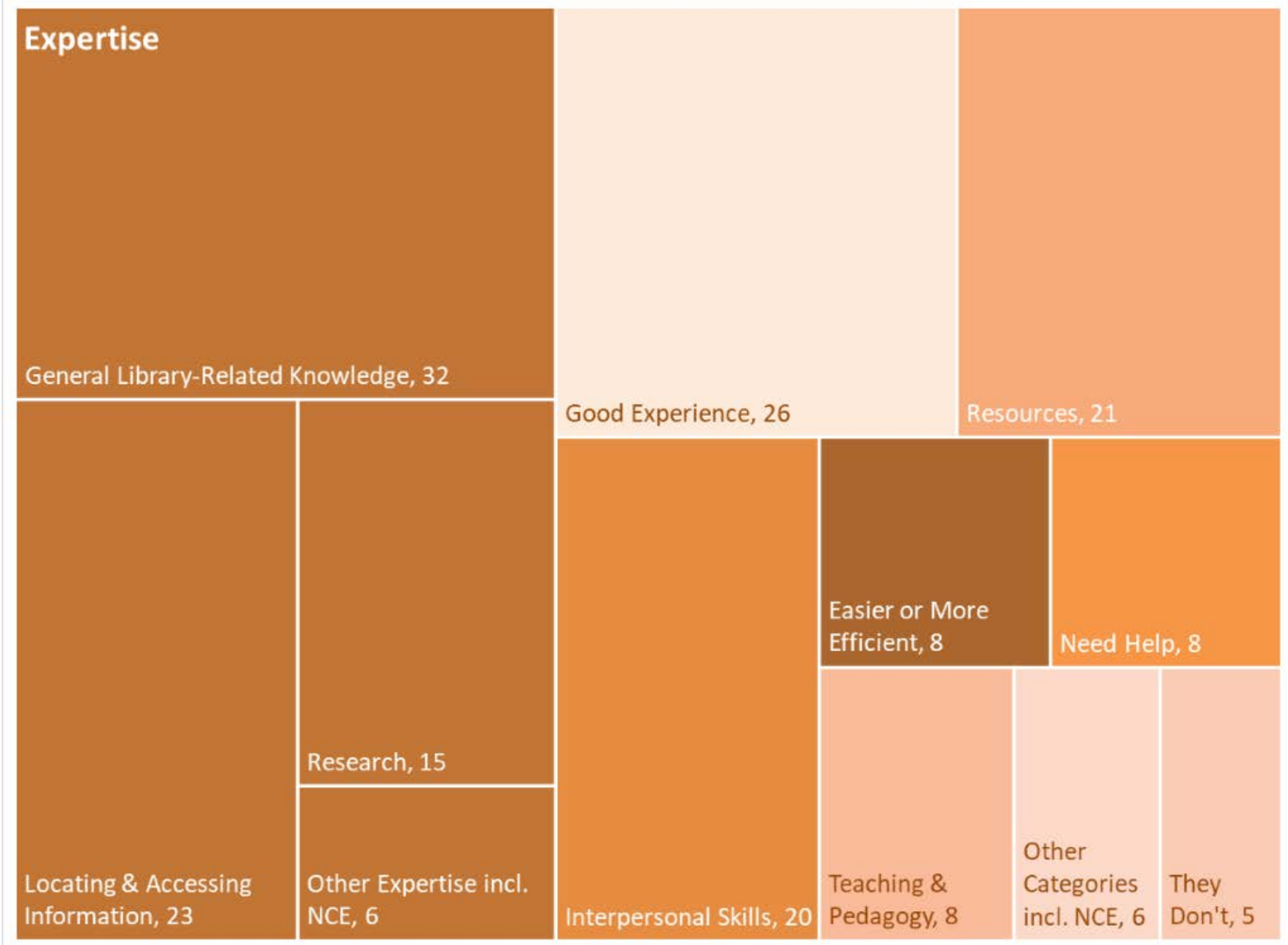

Table 3. Definitions for coding responses to "Why do you like to ask librarians questions?" (Q13).

\begin{tabular}{|c|c|c|}
\hline \begin{tabular}{|l} 
Category / \\
Subcategory
\end{tabular} & Description & $\begin{array}{l}\text { Example Responses in Faculty } \\
\text { Survey }\end{array}$ \\
\hline \begin{tabular}{|l} 
Easier or More \\
Efficient \\
\end{tabular} & Saving time or effort. & $\begin{array}{l}\text { "efficiency" } \\
\text { "To speed up the search process" }\end{array}$ \\
\hline \begin{tabular}{|l|} 
Expertise / \\
Evaluating \\
Information \\
\end{tabular} & $\begin{array}{l}\text { An ability to determine the quality of } \\
\text { information or sources. }\end{array}$ & $\begin{array}{l}\text { "Because they know more than I } \\
\text { do about finding good sources" }\end{array}$ \\
\hline \begin{tabular}{l|} 
Expertise / General \\
Library-Related \\
Knowledge \\
\end{tabular} & Librarians "knowing stuff.” & $\begin{array}{l}\text { "They are knowledgeable" } \\
\text { "Because they often have } \\
\text { answers" }\end{array}$ \\
\hline \begin{tabular}{|l|} 
Expertise / \\
Locating and \\
Accessing \\
Information \\
\end{tabular} & $\begin{array}{l}\text { Accessing or finding needed information. } \\
\text { Usually also coded with a particular type of } \\
\text { resource (databases, books, articles, data, } \\
\text { etc.). }\end{array}$ & $\begin{array}{l}\text { "finding and obtaining resources" } \\
\text { "It is mostly to locate materials I } \\
\text { need for my research or teaching" }\end{array}$ \\
\hline \begin{tabular}{|l} 
Expertise / \\
Research
\end{tabular} & $\begin{array}{l}\text { Research used as a noun, adjective, or verb. } \\
\text { Usually focused on processes. }\end{array}$ & $\begin{array}{l}\text { "research-based questions for } \\
\text { myself or classes" } \\
\text { "usually to help with research" }\end{array}$ \\
\hline $\begin{array}{l}\text { Expertise / Subject } \\
\text { Areas }\end{array}$ & $\begin{array}{l}\text { References either knowledge across many } \\
\text { topics (General Education expertise) or } \\
\text { subject specialties depending on position. }\end{array}$ & "they are subject specialists" \\
\hline
\end{tabular}




\begin{tabular}{|c|c|c|}
\hline $\begin{array}{l}\text { Expertise / } \\
\text { Technology }\end{array}$ & $\begin{array}{l}\text { Computers, software, or technology } \\
\text { management skills. }\end{array}$ & $\begin{array}{l}\text { "new technologies" } \\
\text { "Librarians have their finger on the } \\
\text { pulse of current technology" }\end{array}$ \\
\hline Good Experience & Past experiences that were helpful or useful. & $\begin{array}{l}\text { "I usually learn something!" } \\
\text { "I always receive a thoughtful, } \\
\text { productive, and helpful response" }\end{array}$ \\
\hline $\begin{array}{l}\text { Interpersonal } \\
\text { Skills }\end{array}$ & $\begin{array}{l}\text { Communication skills, customer service } \\
\text { skills, social skills, or personal qualities such } \\
\text { as "patient” or "intelligent.” }\end{array}$ & $\begin{array}{l}\text { "they are helpful" } \\
\text { "they're very interesting people" }\end{array}$ \\
\hline Need Help & A general need for information or assistance. & $\begin{array}{l}\text { "because I need an answer to some } \\
\text { query" } \\
\text { "if I need" }\end{array}$ \\
\hline Resources & $\begin{array}{l}\text { Materials mentioned generically (holdings, } \\
\text { resources, stuff, etc.) or specifically (data, } \\
\text { articles, books, films, etc.). Includes the } \\
\text { concept of collection management. Often also } \\
\text { coded at expertise in locating/accessing } \\
\text { information. }\end{array}$ & $\begin{array}{l}\text { "finding and obtaining resources" } \\
\text { "They think of databases I have not } \\
\text { thought of" }\end{array}$ \\
\hline Stumped or Lost & $\begin{array}{l}\text { Being stuck or having no idea how to start. } \\
\text { More pointed than references to generally } \\
\text { wanting or needing help. }\end{array}$ & $\begin{array}{l}\text { "I need to find information and } \\
\text { have no idea where to look" } \\
\text { "I need to find stuff I can't find" }\end{array}$ \\
\hline $\begin{array}{l}\text { Teaching and } \\
\text { Pedagogy }\end{array}$ & $\begin{array}{l}\text { Teaching and instruction for individuals and } \\
\text { groups, as well as mentions of student } \\
\text { learning or pedagogical practices. Also } \\
\text { includes assistance provided to improve } \\
\text { others' teaching. }\end{array}$ & $\begin{array}{l}\text { "how to teach students about } \\
\text { information \& data" } \\
\text { "To give in-class training for } \\
\text { students as they begin a research } \\
\text { project" }\end{array}$ \\
\hline They Don't & $\begin{array}{l}\text { Rejections of the premise of the question - } \\
\text { they don't ask librarians questions. }\end{array}$ & $\begin{array}{l}\text { "I don’t usually" } \\
\text { "I really don’t like to ask } \\
\text { questions.” }\end{array}$ \\
\hline
\end{tabular}

The most common response was a reference to librarians’ expertise, with many references to expertise in general library-related knowledge (32 mentions). Examples of this type of response are "because they are very knowledgeable in what they do" and "because I believe they are experts.” Respondents also specified librarians’ expertise in Locating \& Accessing Information (23 mentions) and Research (15 mentions). Some respondents said they asked librarians for help because it was easier or more efficient (8 mentions), using language such as "librarians are one-stop shopping for help!” and “saves me time.” Even more frequently, they associated asking librarians for help with the idea of Resources (21 mentions).

Another common theme was respondents citing good experiences that they have had with librarians (26 mentions), such as "Because they love questions! Every time I've asked 
I've been offered many paths to the destination, and often the exchange produces some valuable insights into my project as a whole” and "I always receive a thoughtful, productive, and helpful response.” This tendency to discuss interactions with librarians in personal terms was seen in the "Need Help” category (8 mentions) and particularly strikingly in the “Interpersonal Skills” category (20 mentions). The respondents described librarians as "helpful,” "support and friendly,” "good people,” “fair and equitable,” “interesting,” and “smart.”

Several respondents also noted that librarians help with Teaching \& Pedagogy (8 mentions). This was framed as support by some (“support in the classroom”) but as shared expertise by others (“incredible partners in teaching”). While not specifically referencing teaching, one respondent also noted that librarians “know what students are asking, so they're often more knowledgeable about the challenges students are facing and the desires they have than we are.”

Seventy-three (58\%) responded to the converse question——Why don't you like to ask librarians questions?” (Q14). Reasons given across responses were coded into several broad categories, as shown in Figure 11. Definitions for these categories are shown in Table 4. The most common response rejected the premise of the question: 25 mentioned that they actually do like to ask librarians questions (among 88 coded references). For those that did cite a reason not to ask librarians questions, Bad Experience was a common response (10 mentions). The mentioned experiences dealt with both the attitude of librarians ("sometimes I've felt judged," "they sometimes act as if they do not have time for my questions") and unsatisfactory results (“they usually tell me why I can’t have a resource or direct me to a resource that is useless or very cumbersome to use”). Another common response was a perceived Lack of Need (10 mentions). This included ideas of self-sufficiency (“don’t need the help”), but most examples emphasized not needing to use library facilities because they 
use it online, such as "I tend to use the library online" and "most things I need are easily accessible online” (6 mentions).

Figure 11. Why faculty DON'T like to ask librarians questions (Q14); Total Respondents=73; Total coded references $=88$.

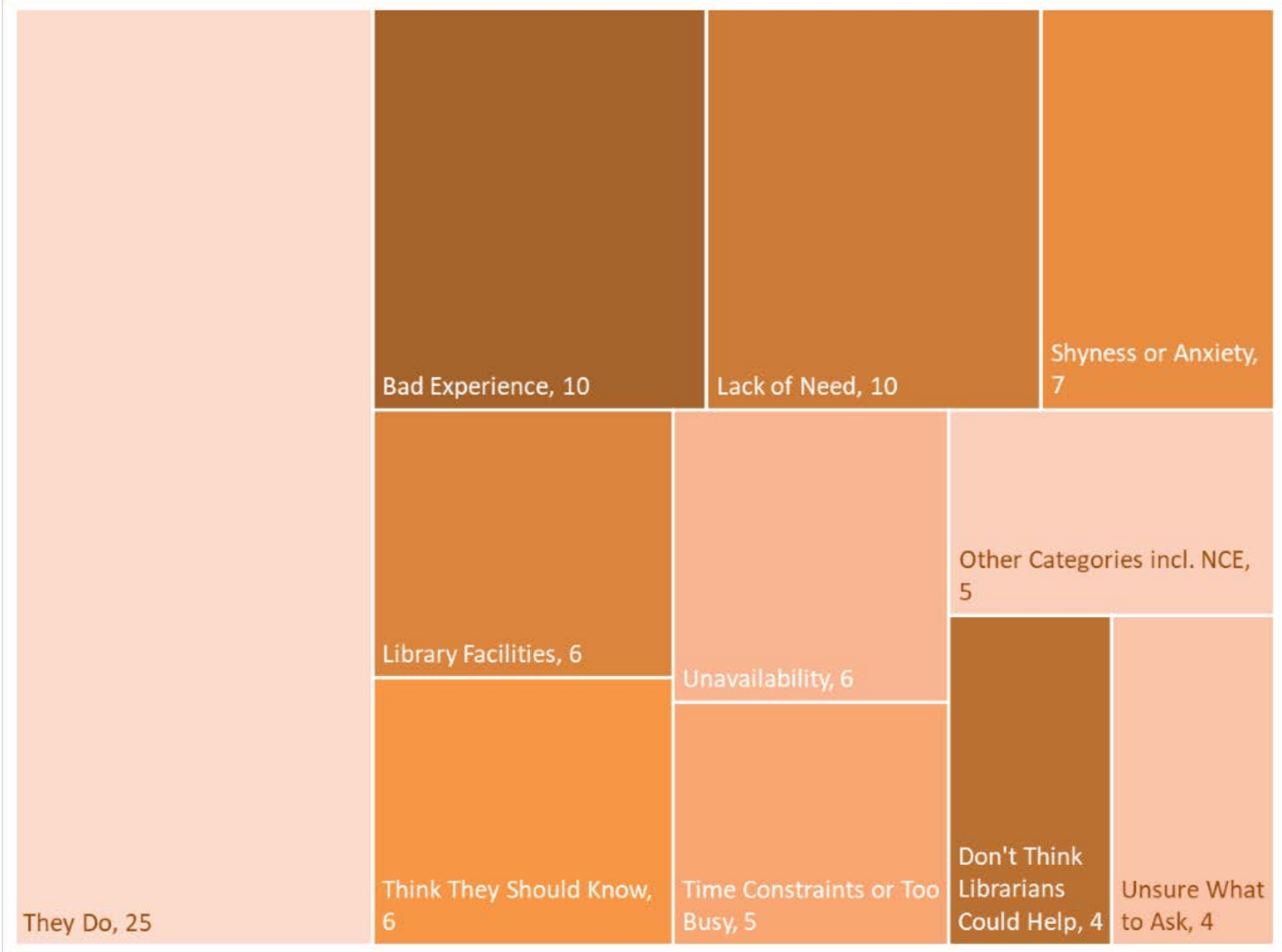

Table 4. Definitions for coding responses to "Why don't you like to ask librarians questions?” (Q14)

\begin{tabular}{|l|l|l|}
\hline $\begin{array}{l}\text { Category / } \\
\text { Subcategory }\end{array}$ & Description & Example responses in FPL \\
\hline Bad Experience & $\begin{array}{l}\text { Past experiences that were not } \\
\text { helpful or useful. }\end{array}$ & $\begin{array}{l}\text { "Sometimes I've felt judged" } \\
\text { "Long wait time to response at time, } \\
\text { not always the response I was hoping } \\
\text { for” }\end{array}$ \\
\hline $\begin{array}{l}\text { Don't Think They } \\
\text { Could Help }\end{array}$ & $\begin{array}{l}\text { Assumptions that librarians } \\
\text { would not have the right } \\
\text { expertise. }\end{array}$ & $\begin{array}{l}\text { "Sometimes seems out of their } \\
\text { wheelhouse” }\end{array}$ \\
\hline Lack of Need & $\begin{array}{l}\text { Faculty feeling like they don't } \\
\text { need help. }\end{array}$ & $\begin{array}{l}\text { "because I don't have any" } \\
\text { "not often in the library because I } \\
\text { access things online” }\end{array}$ \\
\hline Preference & $\begin{array}{l}\text { Specific choices or inclinations } \\
\text { for getting help or information. }\end{array}$ & $\begin{array}{l}\text { "if I can be self-sufficient I prefer } \\
\text { that" } \\
\text { "I like to find my own answers" }\end{array}$ \\
\hline
\end{tabular}




\begin{tabular}{|c|c|c|}
\hline Should Know & $\begin{array}{l}\text { Belief that they should know the } \\
\text { answer or not need help. Often } \\
\text { accompanied by emotional } \\
\text { responses as well. }\end{array}$ & $\begin{array}{l}\text { “'Because it reveals how little I } \\
\text { actually know about how to do } \\
\text { research!” } \\
\text { “feel bad for not knowing what’s } \\
\text { probably basic stuff” }\end{array}$ \\
\hline Shyness or Anxiety & $\begin{array}{l}\text { Emotional responses to asking } \\
\text { for help. Includes fear of looking } \\
\text { stupid, intimidation, } \\
\text { awkwardness, etc. }\end{array}$ & $\begin{array}{l}\text { "too shy" } \\
\text { "don’t want to bother them" }\end{array}$ \\
\hline They Do & $\begin{array}{l}\text { Rejections of the premise of the } \\
\text { question - they do like to ask } \\
\text { librarians questions. }\end{array}$ & $\begin{array}{l}\text { “Doesn’t apply” } \\
\text { "I have no problem asking librarians } \\
\text { questions!” }\end{array}$ \\
\hline $\begin{array}{l}\text { Time Constraints or } \\
\text { Too Busy } \\
\end{array}$ & Faculty being too busy. & $\begin{array}{l}\text { “"Because sometimes I am busy” } \\
\text { “time constraints” }\end{array}$ \\
\hline Unavailability & $\begin{array}{l}\text { Not being able to find librarians } \\
\text { or having difficulty contacting } \\
\text { them. Distinct from not being } \\
\text { aware that librarians could help. }\end{array}$ & $\begin{array}{l}\text { "sometimes hard to find the right } \\
\text { one, and their offices are tucked } \\
\text { away from the public" } \\
\text { "Access - sometimes they're not } \\
\text { easy to get to when I have a } \\
\text { question" }\end{array}$ \\
\hline Unsure What to Ask & $\begin{array}{l}\text { Not knowing how to ask the right } \\
\text { questions to get the information } \\
\text { they are seeking. Distinct from } \\
\text { not being aware that librarians } \\
\text { could help. }\end{array}$ & $\begin{array}{l}\text { "I may not have my question } \\
\text { formatted correctly" } \\
\text { "Sometimes I don't know exactly } \\
\text { what questions to ask" }\end{array}$ \\
\hline
\end{tabular}

Some faculty respondents also expressed emotional stress around asking questions.

Shyness or anxiety was a common emotion (7 mentions), which appeared in language such as "too shy” and "don’t want to bother them.” Another common emotion was thinking that they should know the answer without having to ask (6 mentions). These responses included "With a PhD, I feel like I should probably know the answers to questions I might ask them," "feel bad for not knowing what’s probably basic stuff,” and "Because it reveals how little I actually know about how to do research!”

A lack of confidence in the process also appeared when respondents noted that they did not think librarians would be able to help (4 mentions) and that they were unsure what to ask (4 mentions). Respondents also cited time constraints, both their own and librarians' (5 mentions), with some specifying that librarians often seemed unavailable (6 mentions). 


\section{Any Additional Comments?}

There were 19 responses to the question, “Any Additional Comments?” (Q18), plus one respondent entered “no” as a response. Seven comments contained statements of appreciation, such as “Keep doing a great job!” while four contained at least one statement of disappointment with the library ("I wish the library were as eager to support scholarship as teaching”) or with a given librarian’s performance (“Current librarian is very effective; prior librarian barely present.” Four respondents noted that their responses would have varied librarian-to-librarian. Six respondents noted issues with the survey, for example, with the scale options or with item phrasing, some finding items "insulting” or "condescending” (one librarian had made similar comments in that survey (Fagan, Ostermiller, Price, \& Sapp, 2020b). Five respondents talked about issues relating to diversity, some with critique of the survey elements, and others related to the library ("I noticed that on the library home page, all the librarians pictured were white women of a similar age.” Finally, five respondents mentioned some piece of feedback related to the overall library, positive or negative, and three comments included some level of individual interest in the research ("I'm curious to know if I got the question right about what people study in library science degree programs...).

\section{Discussion}

\section{What Librarians Know: Librarian expertise and value for librarians’ skills}

The literature review found few direct investigations of faculty perceptions regarding librarians’ knowledge, skills, and experience (Fagan, Ostermiller, Price, \& Sapp), 2020a, p. 15). What perceptions faculty do have "are primarily informed by domains in which they have been engaged with a librarian” (p. 17). The present study found a large majority of faculty at JMU had accurate views of librarians' educational qualifications but had a lowerthan-actual perception of what entry-level salaries might be. Across the three questions 
related to education and skills, faculty emphasized Expertise, often in the outward facing areas where librarians' work is more likely to intersect with them (Research, Locating \& Accessing Information) and Resources (the stuff they use). This mirrors the literature review’s summary of faculty recognition for information-seeking skills (Fagan, Ostermiller, Price, \& Sapp), 2020a, p. 16) and to a lesser extent, collections (p. 17).

Hall (2009) reported that almost 70\% of LIS programs required a Reference skillsrelated course (p. 65). The term Reference is professional jargon, so it is not surprising that it was scarcely mentioned by faculty respondents ( 2 mentions, less than $1 \%$ of coded references). By way of contrast, Reference Skills \& Reference Interviews figured prominently in librarians' perceptions of their own ability to help with Research and Locating \& Accessing Information, and which appeared in $14 \%$ of coded references on the librarian survey (Fagan, Ostermiller, Price, \& Sapp, 2020b). In Saunders’s recent study (2020) of core skills for academic librarians, several concepts were found underlying librarians’ understanding of Reference: customer service and interpersonal skills (p. 303); the reference interview, which includes active listening, approachability, interest, open-ended questioning, and reservation of judgment (p. 303); question negotiation (p. 298); and search skills (p. 301). Yet some of these-customer service, interpersonal communication, search skills—also stood on their own alongside Reference in Saunders’s “top ten” core skills (pp. 297-298). Faculty responses to this survey indicated awareness of and value for librarians' customer service, helpfulness, and search skills, building on the literature review’s finding that faculty “perceive librarians as helpful with gathering information for their own research and that of their students” (Fagan, Ostermiller, Price, \& Sapp, 2020 p. 16). It is unclear whether these expressions of value indicate an awareness of the Reference activity among faculty. Certainly, some nuanced aspects of reference, such as the interview, did not seem to be on the faculty radar. Therefore, we conclude that while some activities underlying Reference are 
valued by faculty, they might not articulate them in the same way librarians do. And, some activities might remain hidden. Furthermore, the overall concept of Reference might no longer hang together as a discrete construct in the minds of faculty. Marketing library services and demonstrating librarians’ value to the university should carefully consider whether and how librarian jargon is necessary to communicate meaningfully about our work. Table 5. Comparison of what librarians said they learned in library school classes (Librarian survey, Q9) with what faculty said they thought librarians learned in their library classes (Faculty survey, Q16).

\begin{tabular}{|l|c|c|c|c|}
\hline Categories & $\begin{array}{c}\text { LPL } \\
\text { CR }\end{array}$ & $\begin{array}{c}\text { Librarian \% } \\
\text { CR }\end{array}$ & $\begin{array}{c}\text { FPL } \\
\text { CR }\end{array}$ & $\begin{array}{c}\text { Faculty \% } \\
\text { CR }\end{array}$ \\
\hline Expertise & 19 & $25 \%$ & 165 & $48 \%$ \\
\hline Organization & 15 & $19 \%$ & 28 & $8 \%$ \\
\hline Resources & 13 & $17 \%$ & 68 & $20 \%$ \\
\hline Reference Skills \& Reference Interviews & 11 & $14 \%$ & 2 & $1 \%$ \\
\hline Teaching \& Pedagogy & 5 & $6 \%$ & 20 & $6 \%$ \\
\hline Data \& Information Management & & & 29 & $8 \%$ \\
\hline NCE & 13 & $17 \%$ & 18 & $5 \%$ \\
\hline Interpersonal Skills & & & 25 & $4 \%$ \\
\hline Library Facilities & & & 2 & $1 \%$ \\
\hline Total Coded References (CR) & 77 & $100 \%$ & 356 & $100 \%$ \\
\hline
\end{tabular}

Similarly, the nuances of Organization beyond classification systems might be harder for faculty users to grasp, which is likely why librarians had a higher percentage of coded references to this concept (19\%) than faculty did (8\%). Organization of Information is a fundamental concept in LIS education; Hall (2009) found that 93\% of LIS programs required a course in Organization of Information, while Joudrey \& McGinnis (2014) found at least one Information Organization course was required per school with an average of 4.1 elective courses per school. Some faculty expected LIS programs to impart knowledge about Teaching \& Pedagogy to librarians (6\% of total coded references), which was similar to results from the survey of librarians. While librarians might wish they learned more about teaching in their degree programs (Fagan, Ostermiller, Price, \& Sapp, 2020b, pp. 9-10), this survey might suggest that LIS programs are not out of line with terminal degree programs in 
other disciplines. Most programs continue to train faculty as disciplinary researchers instead of as instructors (Robinson \& Hope, 2013); therefore, faculty would not expect the library and information science discipline to operate differently. The failure of graduate programs to include more pedagogical training is “common and longstanding” in higher education (Keith, 2019), hence librarians are not alone in feeling underprepared. Perhaps this indicates that librarians should shift their perspective-they are receiving as much (or more) pedagogical training as disciplinary faculty and should not be so hesitant to own their teacher identities more prominently.

The frequency with which faculty mentioned Data \& Information Management as a topic covered in LIS curriculum was surprising, particularly because this category was not once coded in the librarian survey data. Faculty responses usually had some combination of those words and little else, making it tough to glean context as to whether faculty thought it was truly part of librarian expertise or just a buzzword. LIS programs have expanded the number of courses and certificate programs in digital/data curation; Keralis (2012) reported five in 2012 while Yang, Ju \& Chung (2019) identified 11 in 2015-16. The high prevalence of mentions of Data \& Information Management in response to this question was even more striking when compared to how little value faculty assigned this skill in subsequent responses.

Regarding librarians’ skills, faculty were asked “What skills do you think librarians have that are valuable to you?” Faculty reported that Expertise (146 mentions) and Resources (68 mentions) were most valuable to them. Examples of what faculty said they valued:

- “They know and can explain resources and opportunities that I do not, and are able to explain them in ways that I can act upon; when they don't know the answers, they look for them.” 
- "I rely on our librarians to safeguard, maintain, and update our university's information infrastructure.”

- "They are an excellent asset to faculty and students alike - helping students learn to search, what to search, how to think through a search process, idea / hypothesis generation .... their help is essential to the education process.”

- "Help with research--familiarity with online resources such as databases; knowing where to find field-specific information; how to borrow/use resources from other libraries such as interlibrary loan.”

This question was phrased differently in the survey to librarians (Fagan, Ostermiller, Price, \& Sapp, 2020b, Appendix LPL-1), where it focused on skills valuable to students. This makes a one-to-one comparison between the faculty and librarian surveys impossible.

When asked about skills valuable to the university, librarians and faculty groups both pinpointed Expertise (Table 6). Nearly half of all coded references fell into this category (49\% and 44\% in each survey, respectively). For faculty, Expertise included Research (51 mentions), Locating \& Accessing Information (25), Subject Areas (13), and Technology (13). The high value assigned to librarians’ information-seeking skills aligns with previous studies (Fagan, Ostermiller, Price, \& Sapp, 2020b, p. 16). In regard to Technology, the literature review had suggested faculty don’t perceive librarians provide IT support but do see roles for librarians to help integrate technology into the curriculum (Fagan, Ostermiller, Price, \& Sapp, 2020b, p. 22). For librarians, Expertise encompassed Research (7 mentions), GeneralLibrary Related Knowledge (5), and Subject Areas (3). Seven items were "not classified elsewhere” (NCE) in the librarian data and included concepts such as scholarly communication trends; service on committees, boards and in the local community; and identifying new skills and support the libraries can offer. The NCE category in the faculty data included grant writing, archival skills, and "efficient, effective and economical library 
operations.” In sum, the faculty view is dominated by librarians’ Expertise with Research and Locating \& Accessing Information, but some faculty are aware of other domains of library knowledge. These findings provide support for continuing to tell our story to our communities, especially as it evolves over time.

Table 6. Comparison of librarian and faculty responses to the question "What skills do you think librarians have that are valuable to the university?” (Librarian survey, Q6; Faculty survey, Q12).

\begin{tabular}{|l|c|c|c|c|}
\hline \multicolumn{5}{|c|}{ Skills valuable to University } \\
\hline & $\begin{array}{c}\text { LPL } \\
\text { CR }\end{array}$ & Librarian \% CR & FPL CR & Faculty \% CR \\
\hline Categories & 28 & $49 \%$ & 131 & $44 \%$ \\
\hline Oxpertise & 7 & $12 \%$ & 16 & $5 \%$ \\
\hline Rrganization & 3 & $5 \%$ & 62 & $21 \%$ \\
\hline Tesources & 7 & $12 \%$ & 21 & $7 \%$ \\
\hline Interpersonal Skills & 7 & $12 \%$ & 18 & $6 \%$ \\
\hline Higher-order Thinking & 3 & $5 \%$ & 7 & $2 \%$ \\
\hline NCE & 2 & $4 \%$ & 31 & $11 \%$ \\
\hline Data and Information & & & 3 & $1 \%$ \\
\hline Management & & & 1 & $0 \%$ \\
\hline Library Facilities & & & 1 & $0 \%$ \\
\hline Unspecified Help & & & & $100 \%$ \\
\hline Total Coded References \\
(CR)
\end{tabular}

Faculty prioritized librarians’ role as stewards of resources as the second most valuable skill to the university (21\% of coded references). This viewpoint wove through multiple questions including what librarians learn in their degree programs ("Database use," “How to find information and articles”); librarians’ value to faculty (“Knowledge of library holdings and databases,” "ability to order books and subscribe to databases and journals”) and librarians' value to the university (“keeping up with resources that faculty/staff would want to use for research and teaching," "what databases we have access to and how to use databases”). Librarians only mentioned Resources as valuable to the university in $5 \%$ of coded references, less frequently than Organization, Teaching \& Pedagogy and Interpersonal Skills (all at $12 \%$ of coded references). With their direct knowledge of how they spend their 
time, and insight into the diversity of their work, librarians might see their work with Resources as having proportionally less influence on university outcomes than the other work they do. Librarians might also downplay our expertise in Resources out of fear that faculty still value their campus library primarily as a “dispensary of goods (i.e., books, articles) rather than a locus for much needed, real-time professional support” (Jahnke \& Asher, 2012, p. 4). This view might be reinforced by Ithaka S+R's triennial faculty survey, which consistently has highlighted the importance of libraries as buyers over other opportunities for support with teaching or research (Blankstein \& Wolff-Eisenberg, 2019). The current study’s finding that Expertise might dominate the minds of faculty more than Resources suggests that librarians should not be afraid to embrace the value of their skills in resource selection. As one faculty respondent noted, librarians have the valuable ability to bring a "critical inquiry lens around information access, database knowledge (both what databases we have access to and how to use databases).” As more information resources become available, faculty rely on librarians to be "up-to-date on current trends and technologies” and "staying on top of changes in technology and how it is impacting the transfer of academic knowledge.” The gap between librarians' and faculty’s perceptions of librarian work related to Resources might not be critical to remedy at the individual level. However, it does point out a potential blind spot in university administration's understanding of the library's role and needed resources, and the need to describe some aspects of librarian work in more detail.

Another topic that is interesting largely because of its absence from this list is Data \& Information Management. While faculty indicated this is a skill librarians learn in library school, this skill is not one they mentioned as valuable to them personally or to the university. Adding to this curiosity, Data was mentioned more frequently than Books when faculty did specify a resource (Figure 12). Ohaji, Chawner and Yoong (2019) suggest that the "research data management role of libraries is expected to grow in the future.” Faculty might 
realize that data management is an emerging concern for them but be unsure of how librarians can help. Further studies examining this disconnect would benefit the profession.

Figure 12. Breakdown of faculty coding for specific types of "Resources” mentioned (Q11, Q12, Q13, Q14, Q16); Total coded references=108. Generic mentions of "Resources" are not shown.

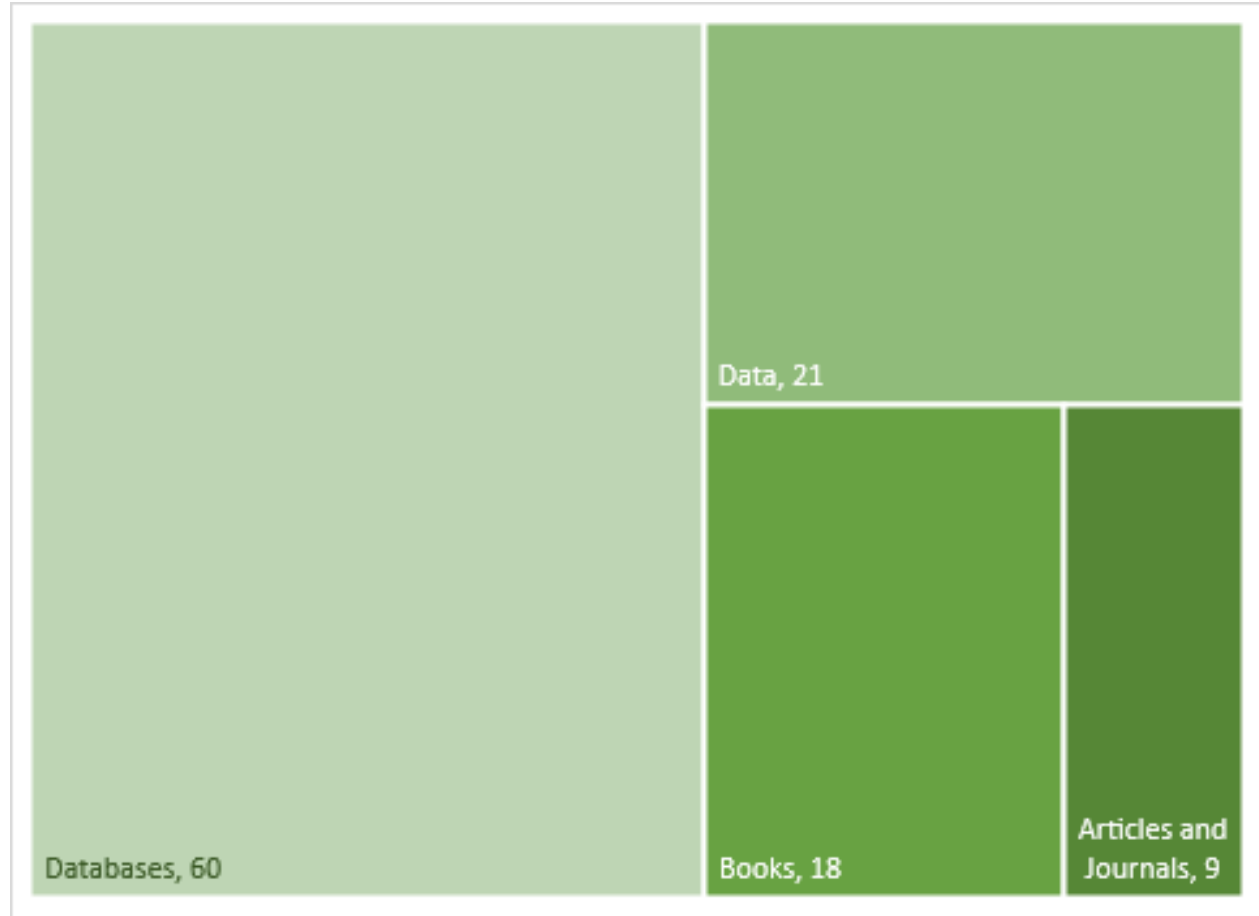

The three questions just discussed each attempted to gather information about what librarians know. Only about half of the respondents answered each of these questions. Thus, responses to these questions might be from a distinctive group not fully representative of the sample, let alone the JMU population. These respondents might be extra-motivated by their affinity for librarians, or they might have more knowledge about librarians, while nonrespondents might have been either less motivated or might not have felt they had sufficiently informed opinions. Among those who did respond, the proportions of responses were quite similar across all three questions, suggesting the questions aren't targeting different mental constructs. This will be discussed further in the "Methodological Improvements" section. 


\section{What Librarians Do: Duties and role of librarians}

Most faculty were aware that JMU librarians are also faculty, and many ask to speak to librarians. This hearkens back to the literature review's findings that faculty value librarians’ instruction for themselves, not just their students (Manuel et al. 2005) and also value librarians’ reference abilities, subject knowledge, and creative skills (Fagan, Ostermiller, Price, \& Sapp, 2020a, 16-17). Faculty assessment of librarians’ duties aligned fairly well with the librarian survey data. Not surprisingly, librarians were more confident about their duties, more often choosing "Frequently" or "Never" than did faculty. There were three items with more than 6 Not Sure Responses on the faculty survey: Repairing Damaged Materials (12), Issuing Library Cards (8), Processing Fines (7), which might be due to the fact that librarians have and might still do these tasks, but faculty also realize the profession has been changing. Faculty responses would indicate librarians’ top duties are helping students (subject-specific and general), buying books, and giving general help to faculty, with teaching research skills and creating subject guides appearing as fifth and sixth. Librarians had rated teaching research skills, subject-specific help to students, buying books, and creating subject guides as their top-most performed duties, with general help to students and marketing library services as fifth and sixth. Giving general help to faculty was a close seventh, however. The eight lowest-ranked duties were the same for both faculty and librarians, with slight variations in rank; however, librarians were much more adamant that they "rarely or never" performed these duties. Figure 13 shows the largest gaps in perceptions of librarian duties between the groups (difference $>=10 \%$ ). Librarians were more likely to report Frequently or Sometimes evaluating student learning, removing outdated books, and helping users to find books than faculty did, while faculty were more likely to respond that librarians process finds, teach software skills, pick up trash, sort and put books back on the shelves, repair damaged materials, and lend materials to users. As mentioned in the 
limitations section, the diverse communications that librarians conduct with faculty were not fully represented in this question set, yet the fact that $95 \%$ of faculty responded that librarians conducted marketing library services "Frequently" or "Sometimes" supports the visibility of the area to faculty, in keeping with the literature review findings (Fagan, Ostermiller, Price, \& Sapp, 2020a, p. 18).

Figure 13. Differences between faculty and librarian perceptions of librarian duties (Librarian survey, Q5, Faculty survey, Q6).

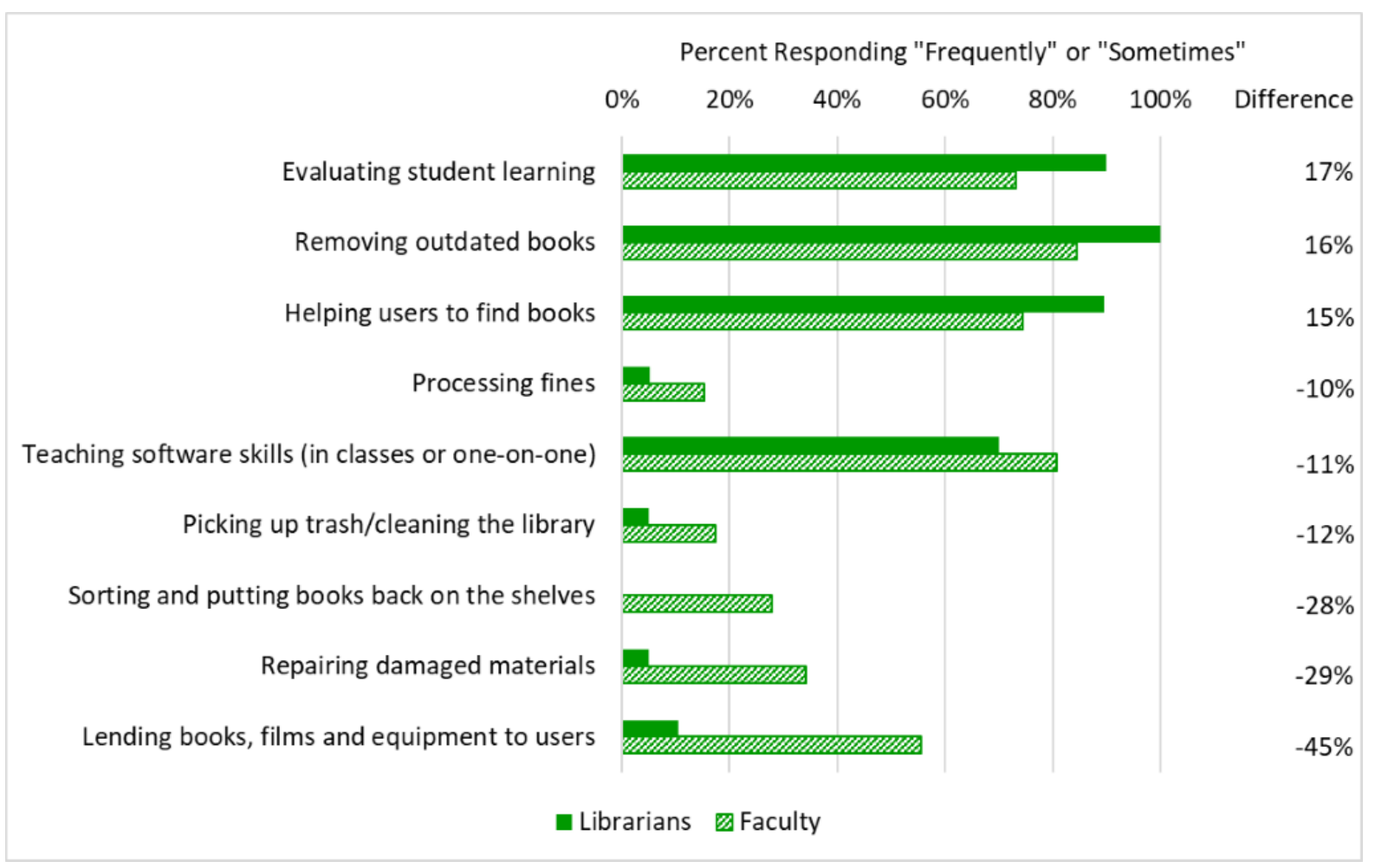

Faculty responses about librarian duties clustered somewhat similarly to the librarian response clusters. All of the duties clustered by librarians into " $C$ ” and " $D$ ” fell into the faculty cluster “C," which seems to map to duties more frequently performed by library staff (e.g. processing finds). Almost all the duties clustered by librarians into either "A" or " $\mathrm{B}$ " fell into either “A” or "B” clusters for faculty. ${ }^{5}$ (To be clear, “A” for librarians does not necessarily look similar to “A” for faculty). For both groups, Clusters A and B together seem

\footnotetext{
${ }^{5}$ Faculty responses suggested two of the librarians' B-cluster responses belonged in faculty cluster “C,” Giving general directional help and Providing IT support for campus Wi-Fi.
} 
to represent the professional work librarians do, suggesting that faculty now have a better distinction between librarians and classified staff. Beyond these broad strokes of agreement, the differences in clustering fail to reveal opportunities to reduce these survey items’ complexity. Furthermore, they do not illuminate the many and diverse summaries of librarian duties in the literature (Fagan, Ostermiller, Price, \& Sapp, 2020a, Table 5). If academic librarians wish to have a clear map of their work, targeted research into the construct seems warranted.

Librarians' teaching and pedagogy did not emerge in faculty minds as strongly as it did in the minds of librarians; this was forecast by interviewees in the Librarian study, who thought faculty members did not see librarians as instructors (Fagan, Ostermiller, Price, \& Sapp, 2020b). Table 7 compares the rank and frequency of teaching and pedagogical duties in the minds of faculty and librarians. Faculty are more likely to perceive librarians as teaching copyright and software skills than librarians think they do, but faculty are less likely to perceive teaching research skills as a Frequently performed duty. And on the qualitative questions regarding librarians’ learning and skills, teaching and pedagogy references represented less than $10 \%$ of mentions. Even though librarians were more vehement about their teaching duties, the fact that $64 \%$ of faculty rated the duty as Frequent mirrors the literature review’s provisional conclusion that librarians' visibility as educators might be increasing from previous decades, when it was often quite low (Fagan, Ostermiller, Price, \& Sapp, 2020b, pp. 19-20). 
Table 7. Comparison of librarian and faculty responses concerning teaching and pedagogy (Faculty survey, Q5; Librarian survey, Q4).

$\begin{array}{llll}\text { FPL } & \text { FPL \% } & \text { LPL } & \text { LPL \% } \\ \text { Rank } & \text { Frequently } & \text { Rank } & \text { Frequently }\end{array}$

Teaching research skills (in classes or one-on-one)

Teaching copyright principles (in

classes or one-on-one)

5

$64 \%$

1

$95 \%$

Teaching software skills (in classes or

one-on-one)

10

$42 \%$

14

$25 \%$

15

$25 \%$

17

$15 \%$

Evaluating student learning

17

$15 \%$

13

$35 \%$

\section{Librarians Are Like: Motivations and affective characteristics}

The literature review found that librarian behaviours do matter to faculty, especially regarding student instruction (Fagan, Ostermiller, Price, \& Sapp, 2020a, p.22). Librarian and faculty rankings for why librarians became librarians were similar, in a broad sense. The lowest ranks (positions 7-10) matched exactly across groups. Both groups had the same reasons in positions 1-3, and the same reasons in positions 4-6, although within those tiers there was some variation. Librarians ranked some reasons for becoming librarians higher (about half a rank or more) than did faculty: "they want to help people,” and "they like working with technology.” Conversely, faculty ranked the reasons "they like books" and “they want to do library research" higher than did librarians.

Because the object of seven items was changed to faculty rather than students, the question set regarding librarian motivations and affective characteristics cannot be compared to the librarian responses on a one-to-one basis. Figure 14 shows the largest gaps $(>=10 \%)$ between faculty and librarians about librarian motivations and affective characteristics on matched items. Faculty were more likely than librarians to respond positively to statements that librarians are experts with technology, are easy to talk to, respect students' intelligence, and have difficult jobs. On a related note, “Librarians know what they’re doing” was the 
statement with the strongest agreement among faculty. The higher positive responses from faculty on these questions support findings in the literature concerning librarians' insecurity and “provider pessimism” (Butler \& Byrd, 2016). Librarians were more likely to respond positively to the statements "Helping students is a librarian's \#1 priority," "It is important to employ librarians of diverse ages, races, and gender," and "There are more female librarians than male librarians.” Librarians also were far less satisfied with the level of diversity among their colleagues than were faculty, with $94 \%$ of librarians responding Somewhat Disagree or Strongly Disagree to "There is enough diversity...”, and only $62 \%$ of faculty responding with disagreement. This finding aligns with how JMU Libraries has made diversity a strategic goal, but also might relate to the faculty's less thorough knowledge of the overall demographics of library faculty. Librarians were in more marked disagreement towards “Librarians are being slow,” (75\% expressed disagreement) than faculty (53.3\% expressed disagreement); and also disagreed more with “Librarians like helping students with projects that are due tomorrow” (79\%) than faculty did (61\%). 
Figure 14. Differences between faculty and librarian perceptions ((Librarian survey, Q11; Faculty survey, Q18).

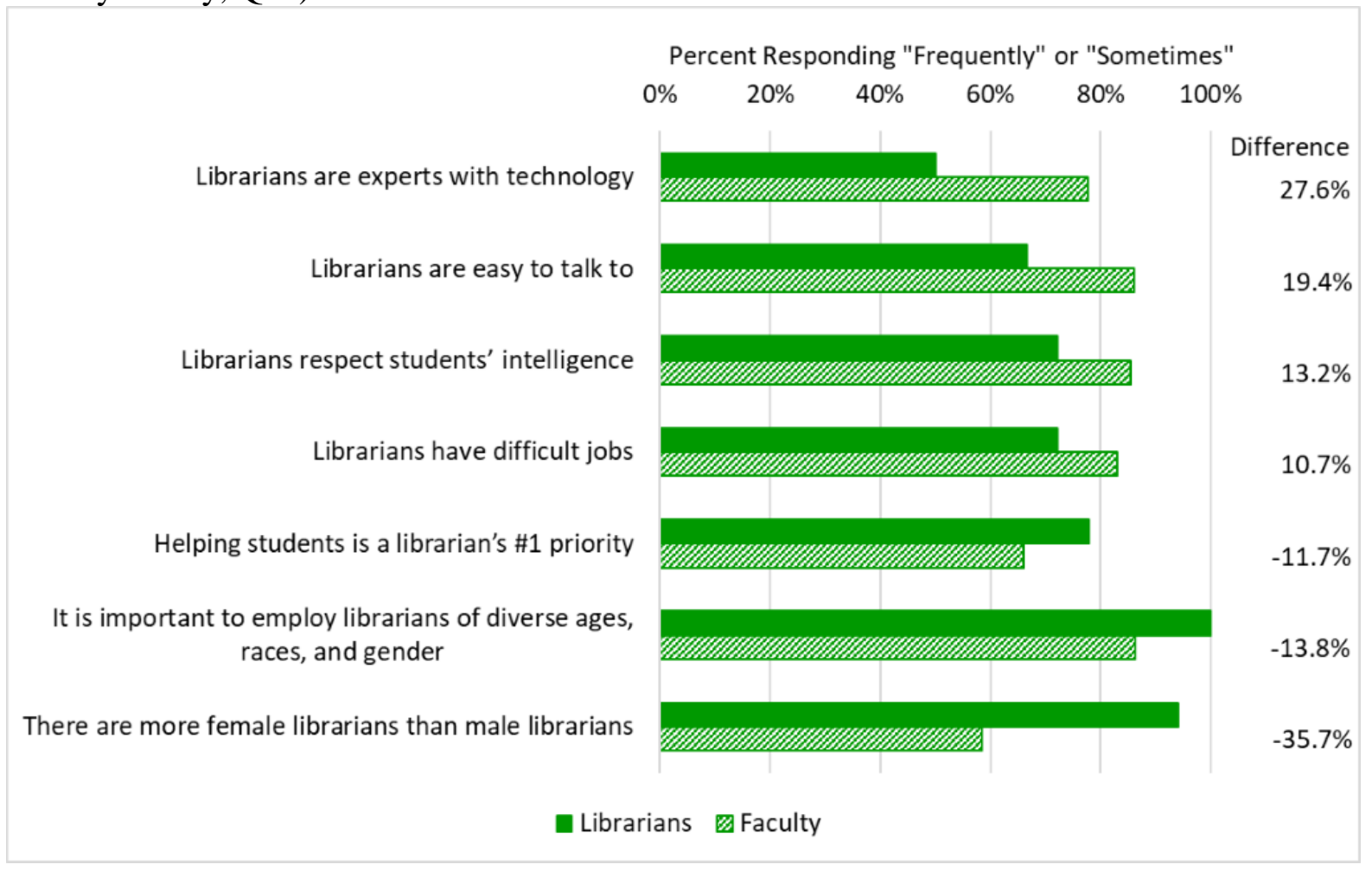

Faculty responses to the affective and motivational questions showed clearer correlation patterns than did the librarians'; however, this is likely due to the much larger sample size of the faculty group. While the librarian response clusters were ambiguous, faculty’s cluster A seemed to relate to librarians’ approachability, motivation to help, and care and respect for students, while Cluster B related to librarians’ knowledge and expertise, their jobs, and diversity among librarians. Most of the negatively correlated items seemed similarly related to Clusters A and B. The researchers are unsure of a common thread underlying all the items in Cluster $\mathrm{C}$, although there seem to be two conceptually related pairs: The ideas that librarians use words students don’t understand and that librarians are slow; and ideas relating to students' preferences for the gender or race of librarians they are approaching for help.

In response to the question "Why do you like to ask librarians questions?” (Q13), the two most common themes were librarians' expertise (32 mentions) and that respondents like 
asking librarians questions because they previously had a good experience (26 mentions). In the librarians' version of the survey, these were also two of the top reasons given in response to the question “Why might students ask librarians questions?” (Fagan, Ostermiller, Price, \& Sapp, 2020b). Although the questions are not exactly parallel because one is about faculty attitudes and one is about student attitudes, the similar results do indicate that librarians have some understanding of how users might perceive them when considering approaching for help.

For the converse prompt, “Why don’t you like to ask librarians questions?” (Q14), librarians generally did not anticipate previous experiences as a reason students would not wish to ask questions (Fagan, Ostermiller, Price, \& Sapp, 2020b). For the faculty respondents, however, a bad experience was one of the most frequently mentioned reasons they don't like to ask questions (10 mentions). There is some indication that previous bad experiences might not have been recent. One respondent specifically noted how interactions with librarians have improved over time: "Prior to the past decade, I had encounters with academic librarians that viewed themselves as gatekeepers to information, which had a subjective judgment aspect to it.”

When sharing why they do ask librarians questions, many respondents described personal qualities of librarians (20 mentions), not just transactional experiences. The responses indicate a general perception of librarians as helpful, knowledgeable, persistent, and curious, all of which are qualities that are necessary for people whom others look to for expertise and for help locating information, which were top categories for this question. More broadly, however, faculty also describe librarians as "good people," "interesting people,” and “fair and equitable.” These responses seem less related to who librarians are in their professional capacity and more descriptive of the perceptions of who librarians are as people. This correlates to additional responses for why respondents believed librarians chose to 
become librarians (Q4), such as “They are awesome people.” With very few exceptions, respondents did not mention librarians' personal qualities at all when answering the question “Why don’t you like to ask librarians questions?” (Q14). These responses also affirm Weng and Murray’s (2019) finding that more faculty had “close/trusting” or “collegial/courteous” relationships with their librarians than “distant” or “indifferent/no thoughts” (p. 206).

The findings concerning faculty perceptions of librarians' motivations and affective characteristics and faculty motivations for asking librarians questions illuminate qualities supportive of collaboration and communication that did not emerge in the "skills" questions. This survey supports Christiansen and colleagues’ (2004) findings that faculty are aware of librarian-faculty collaboration, as well as Jeffries’ (2000) findings that faculty perceive librarians as networkers and collaborators in ways that are complementary to their own roles. Suggestions for building collaboration include furthering awareness of how faculty collaborate with other librarians, including assessment and curriculum development (Ducas \& Michaud-Oystryk, 2003), and capitalizing on opportunities for collaboration already recognized by faculty: collection decisions, notifications of new publications, and information about copyright (Arendt \& Lotts, 2012). Weng and Murray’s study of faculty found that faculty were more likely to hold librarians responsible for enhancing effective partnerships than faculty themselves $(2019,209)$. Finally, we recall the literature's conclusion that faculty status enhances collaboration with non-librarian faculty (Galbraith, Garrison, \& Hales, 2016; Thompson, 2014).While most survey respondents knew that JMU librarians have faculty status, this aspect did not come up extemporaneously, which was also the case with the librarian sample (Fagan, Ostermiller, Price, \& Sapp, 2020b).

\section{Additional Findings}

A significant theme that emerged organically from this survey across qualitative responses is that respondents see librarians as people who can effectively act as conduits 
between faculty and students. Queries using the words "student” and "faculty” in Q12 show 18 responses for the former term and 12 for the latter. One respondent explained that librarians "know what students are asking, so they're often more knowledgeable about the challenges students are facing and the desires they have than we are.” Others saw librarians' "awareness of student culture" as valuable both to faculty and to the university. These descriptions of librarians' role as connectors is a more positive and valued framing than positioning this work as purely supportive, such as the findings in Weng and Murray’s (2019) study, where the "vast majority of [additional] comments centered on librarians' academic adjacent or traditional support roles” (p. 209). The idea that librarians have additional insight into student life and student needs extends to a more general perception that librarians have broad insight into the university, and even into postsecondary education as a whole. Respondents described librarians as having a “bird’s-eye view into research trends in colleges and broadly in higher education” and a "broad, pan-university perspective.”

While the faculty status of librarians might not be top of mind for either librarians or faculty, at least some faculty view librarians and their work as integral to the academic community. One respondent described librarians as the "backbone of research and scholarship," and another as "crucial to the success” of the university, faculty and students. A third respondent elucidated: "None of the work that's being done in any discipline or any major can be done well without the expertise and support of library faculty. They are a vital part of learning on this and any campus.” Librarians function as key components of academic infrastructure; but as in other areas, the importance of infrastructure might be taken for granted occasionally or might not resonate equally with all constituents. This chasm shouldn’t necessarily worry librarians. Weng and Murray (2019) found that even when faculty don't personally take advantage of librarian services, they still see libraries' value to the university: “The percentage of faculty who felt librarians' relevance was critical in 
assisting either their own teaching (17\%) or research (25\%) was significantly lower than those who felt librarians’ institutional roles were very important in teaching (37\%) and research (62\%). Librarians were perceived as having played an important role in institutionwide teaching and research but were less relevant in assisting individual faculty members’ teaching and research” [emphasis added].

\section{Future research}

The literature review offered several discipline-specific findings (Fagan, Ostermiller, Price, \& Sapp, 2020a). This survey’s respondents were representative of the JMU population's colleges, but length prohibited a deeper dive into disciplinary differences in faculty perceptions. We hope to further analyse this data in future scholarship.

Even amid new research such as Saunders (2020), the structure of academic librarians' jobs is still hard to define because it is diverse and evolving. It is interesting that librarians lament “faculty don’t know what we do!” but they themselves also struggle to define what they do. It also seems unrealistic to expect non-librarian faculty to be aware of the diversity of librarian jobs, when librarians themselves struggle to keep up with all the emerging roles. Whether it is important for faculty to understand broad concepts like Information Literacy and Reference is also unclear. This conundrum points out the need for librarians to continue marketing our services while perhaps setting aside the expectation that “faculty ought to know.” Future research could seek to offer a simplified framework for defining academic librarianship that would be useful for labour studies and comparisons, LIS curricula, and academic library marketing.

\section{Methodological Improvements}

The results of this survey offer suggestions for methodological improvements in addition to those discussed in the Limitations section as well as those discussed in the article 
presenting the librarians’ results Fagan, Ostermiller, Price, \& Sapp, 2020b). Responses to the questions “Do you think academic librarians are faculty at every university?” and "In JMU Libraries, can you tell which workers are librarians?” pointed up the insufficiency of the response options: there was no way for users to indicate what might be the most apropos answers; that academic librarians are faculty only at some universities, and that one can sometimes tell which workers are librarians. The similarity of responses to the three "library school” and "valuable skills" questions attempting to target librarian knowledge suggests that future research concerning faculty perceptions should avoid an overly granular approach, as librarians seem to make finer distinctions concerning their work than do faculty, who reasonably have a broader-stroke mental model of librarians and their work. Unless one's research question particularly concerns what non-librarian faculty think happens in library school, we would recommend removing that question and combining the "value" questions into one (i.e., "What knowledge, skills, and abilities do librarians have that is valuable to you, to the university, or both?").

\section{Conclusion}

The perceptions of JMU faculty about librarians were fairly in-line with those of the librarians themselves, if occasionally incomplete. Understandably, responses centred on the activities in which faculty are directly involved, such as information-seeking skills and the use of resources. Faculty more frequently mentioned resources than did librarians and were less aware of the organization that might be required to provide resources and services. Reference did not emerge as a construct on this survey, but some of the skills underlying reference were clearly valued. Overall, this study finds that faculty value librarians’ knowledge, skills, and abilities highly—at least, those that they are aware of. Faculty do seem to distinguish professional librarians’ work from that of library staff. This study identified 
faculty value for interpersonal and behavioural qualities that upholds the literature review's conclusion that faculty increasingly value librarians as collaborators. Indeed, faculty might have a higher opinion of librarians' expertise, approachability, and value than librarians themselves do. Librarians also seem more adamant about their work being inherently serviceoriented than do faculty. While this study showed faculty recognize librarians play a teaching role, it further confirmed that librarians' conception of themselves as teachers is more dominant in their own minds than in the minds of faculty. This survey indicates that librarians at JMU can feel confident that faculty value them as colleagues but should not cease efforts to explain relevant aspects of library work that might otherwise be hidden. Finally, it is encouraging that both groups recognize the importance of diversity in libraries, as well as the progress the profession still needs to make in order to meet our expectations. The next paper in this series will present results from the student version of this survey, with analysis across all three groups.

\section{Disclosure statement}

No potential conflicts of interest reported by the authors

\section{Notes}

1 Four faculty preferred not to say, and one responded "Other" with no text response. These 5 were not included in the chi-square test.

2 Ten faculty said they had multiple roles, and 1 faculty responded "Other"; there was no opportunity for text response. These 11 were not included in the chi-square test.

3 An exploratory factor analysis was attempted, but even after removing some of the items with low correlations with other items, the determinant of the correlation matrix was not sufficient to support the method.

4 The determinant of the correlation matrix for Q27-28 was insufficient for an exploratory factor analysis, probably due to the large number of Not Sure items.

5 Faculty responses suggested two of the librarians' B-cluster responses belonged in faculty cluster "C," Giving general directional help and Providing IT support for campus Wi-Fi. 


\section{References}

Allard, S. (2017). Librarians everywhere. Library Journal, 142(17), 28-34. Retrieved from https://www.libraryjournal.com/?

Arendt, J., \& Lotts, M. (2012). What liaisons say about themselves and what faculty say about their liaisons, a U.S. survey. portal: Libraries and the Academy, 12(2), 155177. doi: 10.1353/pla.2012.0015

Blankstein, M., \& Wolff-Eisenberg, C. (2019, April 12). Ithaka S+R US faculty survey 2018. Retrieved from https://doi.org/10.18665/sr.311199

Butler, K., \& Byrd, J. (2016). Research consultation assessment: Perceptions of students and librarians. Journal of Academic Librarianship, 42(1), 83-86. doi:10.1016/j.acalib.2015.10.011

Christiansen, L., Stombler, M., \& Thaxton, L. (2004). A report on librarian-faculty relations from a sociological perspective. The Journal of Academic Librarianship, 30(2), 116121. doi:10.1016/j.acalib.2004.01.003

Ducas, A. M., \& Michaud-Oystryk, N. (2003). Toward a new enterprise: Capitalizing on the faculty/librarian partnership. College \& Research Libraries, 64 (1). doi: https://doi.org/10.5860/crl.64.1.55

Fagan, J. (2003). Students' perceptions of academic librarians. Reference Librarian, 37(78), 131. doi:10.1300/J120v37n78_09

Fagan, J. C., Ostermiller, H., Price, E., \& Sapp, L. (2020a). Librarian, faculty, and student perceptions of academic librarians: Study introduction and literature review. New Review of Academic Librarianship, 1 -32. Advance online publication. doi:10.1080/13614533.2019. 1691026 
Fagan J.C., Ostermiller H., Price E. \& Sapp, L. (2020b) Academic Librarian Perceptions of Academic Librarians: Building a Foundation of Shared Understanding, New Review of Academic Librarianship, DOI: 10.1080/13614533.2020.1765817

Galbraith, Q., Garrison, M., \& Hales, W. (2016). Perceptions of faculty status among academic librarians. College \& Research Libraries, 77 (5), 582-594. doi:10.5860/crl.77.5.582

Hall, R. A. (2009). Exploring the core: An examination of required courses in ALAaccredited. Education for Information, 27(1), 57-67. doi:10.3233/EFI-2009-0872 Hernon, P., \& Pastine, M. (1977). Student perceptions of academic librarians. College and Research Libraries, 38, 129-139. doi:10.5860/crl_38_02_129

Jahnke, L., Asher, A., Keralis, S. D. C., \& Henry, C. (2012). The problem of data. CLIR Issues, 88, 1. Retrieved from https://www.clir.org/pubs/issues/

James Madison University Office of Institutional Research. (2018). James Madison University - Fact Book 2018. Retrieved from https://www.jmu.edu/oir/oirresearch/statsum/2018-19/T4-2__2018.pdf

Jeffries, S. (2000). The collaborative imperative: Librarians and faculty working together in the information universe. (Raspa \& D. Ward Ed.), American Library Association. Joudrey, D. N., \& McGinnis, R. (2014). Graduate education for information organization, cataloging, and metadata. Cataloging \& Classification Quarterly, 52(5), 506-550. doi:10.1080/01639374.2014.911236

Keith, C. J. (2019). Faculty members' use of learner-centered instruction at institutions in the United States. International Journal of Teaching \& Learning in Higher Education, 31(3), 378-389. Retrieved from http://www.isetl.org/ijtlhe/ 
Manuel, K., Beck, S. E., \& Molloy, M. (2005). An ethnographic study of attitudes influencing faculty collaboration in library instruction. Reference Librarian, 89/90, 139. Retrieved from https://www.tandfonline.com/loi/wref20

Ochola, J. N., \& Jones, P. J. (2001). Assessment of the liaison program at Baylor University. Collection Management, 126 (4), 29-41. doi:10.1300/J105v26n04_03

Ohaji, I. K., Chawner, B., \& Yoong, P. (2019). The role of a data librarian in academic and research libraries. Information Research, 24(4), N.PAG. Retrieved from http://informationr.net/ir/index.html

Robinson, T. E., \& Hope, W. C. (2013). Teaching in higher education: Is there a need for training in pedagogy in graduate degree programs? Research in Higher Education Journal, 21 Retrieved from https://www.aabri.com/rhej.html

Saunders, L. (2020). Core knowledge and specialized skills in academic libraries. College \& Research Libraries, 81(2), 288-311. Retrieved from https://crl.acrl.org/index.php/crl

Schulte, S. J., \& Sherwill-Navarro, P. (2009). Nursing educators' perceptions of collaboration with librarians. Journal of the Medical Library Association, 97(1), 56-59. doi:10.3163/1536-5050.97.1.013

Thompson, C. (2014). Disciplinary differences between faculty in library use and perceptions (Dissertation) Retrieved from ProQuest Dissertations \& Theses Global

Weng, C. \& Murray, D. (2019). Faculty Perceptions of Librarians and Library Services: Exploring the Impact of Librarian Faculty Status and Beyond. Paper presented at the Association of College and Research Libraries Conference Proceedings, Cleveland, OH (pp. 200-210).

Yang, S, Ju, B., Chung, H. (2019). Identifying topical coverage of curricula using topic modeling and visualization techniques: A case of digital and data curation. 
International Journal of Digital Curation, 14(1), 62-87. doi:

https://doi.org/10.2218/ijdc.v14i1.586

Yang, Z. Y. (. (2000). University faculty's perception of a library liaison program: A case study. The Journal of Academic Librarianship, 26 (2), 124-128. doi: 10.1016/S00991333(99)00149-4

\section{Appendix: Faculty Perceptions of Academic Librarians Survey Instrument}

IRB, protocol No. 17-0549

Note: for the purposes of this survey, the phrase "academic librarians" will refer to librarians who work in libraries at universities like James Madison University.

\section{Demographics}

1. I identify as ... - Selected Choice: $1=$ Female, $2=$ Genderqueer or gender fluid, 3=Male, 4= Other [with optional text entry], 5=Prefer not to say.

2. I am ... - Selected Choice: Full-time instructional faculty (1), Part-time instructional faculty (2), Other (full-time administrator or professional staff who teach part-time) (3)

3. The primary college in which I teach is ... - Selected Choice: College of Arts \& Letters (1), College of Business (2), College of Education (3), College of Health and Behavioral Studies (4), College of Integrated Science \& Engineering (5), College of Science \& Math (6), College of Visual \& Performing Arts (7), University Studies (8)

\section{The Librarian Job}

4. Please drag and drop the following reasons librarians chose to become librarians 1-9, where 1 is the top reason that librarians want to be librarians. You may write in another reason and rank it, too.

- they want to work in the university library environment (scholarly, quiet, etc.)

- they like books

- attractive wages and benefits

- they want to do library research

- the prestige accompanying the job

- they want to help people

- they like working with information

- they like working with technology

- it's an easy job

- other 
5. How often do you think academic librarians perform the following duties?

1= Frequently, 2=Sometimes, 3=Rarely, 4=Never, 5=Not Sure

- Issuing library cards

- Helping users to find books

- Lending books, films, equipment to users

- Processing fines

- Giving general directional help

- Buying books, journal and electronic materials

- Removing outdated books

- Creating Subject Guides

- Giving general help to students for research

- Giving subject-specific help to students for research

- Giving general help to faculty for research

- Sorting and putting books back on the shelves

- Evaluating student learning

- Creating online tutorials

- Repairing damaged materials

- Planning special events at the library

- Publishing research about the library profession

- Working in Starbucks

- Supporting library computers/printers/photocopiers

- Providing IT support for campus wi-fi

- Teaching research skills (in classes or one-on-one)

- Teaching software skills (in classes or one-on-one)

- Teaching copyright principles (in classes or one-on-one)

- Marketing library services and programs

- Analysing the effectiveness of library services and programs

- Picking up trash/cleaning the library

6. In the JMU Libraries, can you tell which workers are librarians?

- Yes

- No

- Not sure

7. In the JMU Libraries, do you ever ask to speak to a librarian?

- Yes

- No

- Not sure

8. Do you think academic librarians are faculty at JMU?

- Yes

- No

- Not sure 
9. Do you think academic librarians are faculty at every university?

- Yes

- No

- Not sure

10. How much do you think an entry-level JMU librarian makes per year?

- Less than $\$ 20,000$

- $\$ 20,000-\$ 29,999$

- $\$ 30,000$ - $\$ 39,999$

- $\$ 40,000$ - $\$ 49,999$

- $\$ 50,000-\$ 59,999$

- $\$ 60,000$ - $\$ 69,999$

- $\$ 70,000-\$ 79,999$

- More than $\$ 80,000$

11. What skills do you think librarians have that are valuable to you? [multiline text entry box]

12. What skills do you think librarians have that are valuable to the university? [multiline text entry box]

13. Why do you like to ask librarians questions? [multiline text entry box]

14. Why don’t you like to ask librarians questions? [multiline text entry box]

\section{Education}

15. What do you think is the minimum level of educational qualifications required to be hired as an entry-level JMU librarian?

- High school degree

- Some college classes

- Bachelor's degree

- Master's degree

- More than one Master's degree

- Doctoral degree

- Multiple doctoral degrees

16. What do you think academic librarians learn in their library classes? Please write at least three topics you think are covered in library school classes: [multiline text entry box]

\section{General Opinions}

17. Please read the following statements carefully and indicate your level of agreement. 
Remember, "Librarians" means academic librarians at a university like JMU 1=Strongly agree, $2=$ Somewhat agree, $3=$ Neither agree nor disagree, $4=$ Somewhat disagree, $5=$ Strongly disagree, $6=$ Not Sure

- Librarians like helping students

- Librarians are slow

- Librarians like helping students with projects that are due tomorrow

- Librarians respect students' intelligence

- Librarians help students learn to do things themselves

- Librarians think people who don’t know the basics about the library are stupid

- Librarians are too busy to help students

- It is faster for me to figure out a tough question myself rather than ask a librarian

- Librarians understand students' time pressures

- Librarians are easy to talk to

- Librarians are willing to change their services to meet patrons' needs

- Librarians use words that I don't understand

- Librarians know what they're doing

- Librarians have difficult jobs

- Helping students is a librarian's \#1 priority

- Librarians have knowledge that is practical to me

- Librarians are friendly and pleasant

- Librarians are experts with technology

- I would rather ask a female librarian for help

- Librarians help me search the internet more effectively

- Knowing more about a librarian's education, skills, job, and personality help me decide whether or not to ask them for help

- There are more female librarians than male librarians

- I would be more willing to approach a librarian of my own race or ethnicity

- There is enough diversity (race, ethnicity, age, gender, etc.) among librarians

- It is important to employ librarians of diverse ages, races, and gender

18. Any additional comments? [multiline text entry box] 